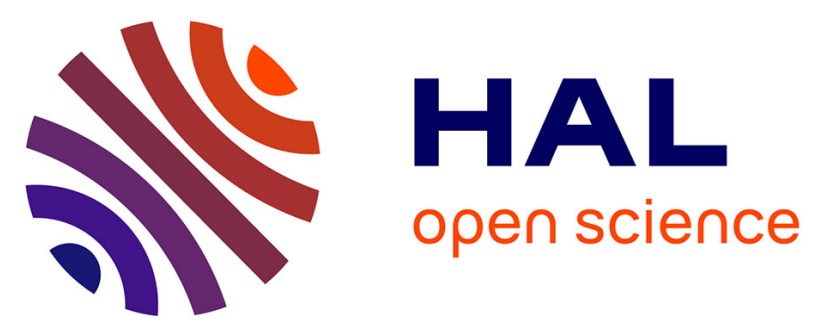

\title{
Apatite LA-ICP-MS U-Pb and fission-track geochronology of the Caño Viejita gabbro in E-Colombia: Evidence for Grenvillian intraplate rifting and Jurassic exhumation in the NW Amazonian Craton.
}

Amed Bonilla, Jose Franco, Thomas Cramer, Marc Poujol, Nathan Cogné,

Simon Nachtergaele, Johan de Grave

\section{To cite this version:}

Amed Bonilla, Jose Franco, Thomas Cramer, Marc Poujol, Nathan Cogné, et al.. Apatite LA-ICPMS U-Pb and fission-track geochronology of the Caño Viejita gabbro in E-Colombia: Evidence for Grenvillian intraplate rifting and Jurassic exhumation in the NW Amazonian Craton.. Journal of South American Earth Sciences, 2021, 108, pp.Art. nº103190. 10.1016/j.jsames.2019.103190 . insu02382089

\section{HAL Id: insu-02382089}

\section{https://hal-insu.archives-ouvertes.fr/insu-02382089}

Submitted on 27 Nov 2019

HAL is a multi-disciplinary open access archive for the deposit and dissemination of scientific research documents, whether they are published or not. The documents may come from teaching and research institutions in France or abroad, or from public or private research centers.
L'archive ouverte pluridisciplinaire HAL, est destinée au dépôt et à la diffusion de documents scientifiques de niveau recherche, publiés ou non, émanant des établissements d'enseignement et de recherche français ou étrangers, des laboratoires publics ou privés. 


\section{Apatite LA-ICP-MS U-Pb and fission-track geochronology of the Caño Viejita gabbro in E-Colombia: Evidence for Grenvillian intraplate rifting and Jurassic exhumation in the NW Amazonian Craton.}

Amed Bonillaa, Jose A. Francoa, Thomas Cramera, Marc Poujolb, Nathan Cognéb, Simon Nachtergaelec \& Johan De Gravec.

a. Geoscience Department, National University of Colombia, Bogotá, Colombia. abonillape@unal.edu.co, Calle 23c \# 69f-65 Int 27 apto 502.

b. Universitè de Rennes, CNRS, Géosciences Rennes - UMR 6118, F-35000 Rennes, France

c. Department of Geology, Ghent University, Krijgslaan 281.S8, WE13, 9000 Ghent, Belgium

\section{ABSTRACT}

17 The 1.80-1.76 Ga crystalline basement in Colombia as part of the W-Amazonian Craton is composed mainly of gneisses, granitoids and migmatites, affected later by several compressive and extensional events resulting for example in A-type granites, but also mafic intrusions and dikes. Here we present, after a revision of main geological features, research results obtained on the NW-SE trending ilmenite-apatite-rich Caño Viejita gabbro in the SW-

22 Vichada department some $500 \mathrm{~km}$ east of Bogota. Petrographic and geochemical data hint to

23 a metaluminous continental alkaline gabbro enriched in $\mathrm{K}, \mathrm{Ti}$ and $\mathrm{P}$, possibly due to 24 continental crust reworking or magma mixing, as also confirmed by trace elements 25 characteristics in the apatites like HREE enrichment $(\mathrm{Ce} / \mathrm{Yb}) \mathrm{cn}$ 12-13, negative Eu-anomaly, 26 and $\mathrm{Y}, \mathrm{Th}, \mathrm{Sr}, \mathrm{Mn}$ ratios. LA-ICP-MS U-Pb apatite geochronology suggests an early 27 Neoproterozoic emplacement age between $975 \pm 9$ and $1002 \pm 21 \mathrm{Ma}$ related with rifting 28 triggered by the Amazonia-Baltica-Laurentia collision during the Rodinia Supercontinent 29 assembly and associated Grenvillian events. These events also caused mafic intrusions in 30 other parts of the craton. Apatite fission track thermochronometry and thermal history 
31 modelling on one sample suggest the onset of the final exhumation stage during Jurassic

32 ( 180 Ma), which brought the rocks slowly to their current outcrop position.

33

34

35

36

37

38

39

40

41

42

43

44

45

46

47

48

49

50

51

52

53

54

55

Keywords: $\mathrm{U}-\mathrm{Pb}$ apatite chronology, apatite fission-track thermochronology, olivine gabbro, Amazonian Craton, Neoproterozoic, Grenvillian.

\section{Introduction}

The Amazonian Craton is one of the largest Precambrian continental nuclei in the world comprising huge parts of NW-South America, mainly in Brazil, but also in Venezuela, Guyana, Suriname, French Guyana and NE-Colombia. It formed during the PaleoMesoproterozoic due to several accretion events, was affected by extensional and crust consuming episodes, which all resulted in complex geochronological provinces (Error! Reference source not found.). These provinces have been (re)defined and refined over the last years and the exact positions of their boundaries is still a matter of debate (Cordani et al., 2009, 1979; Kroonenberg, 2019; Santos et al., 2000; Tassinari and Macambira, 1999; Teixeira et al., 1989). The NW Amazonian Craton that outcrops in Eastern Colombia yields ages between $\sim 1.86-1.70 \mathrm{Ga}$ and is defined as part of the Mitú Migmatitic Complex (Galvis et al., 1979; Rodríguez et al., 2011) or better the Mitú Complex (Bonilla et al., 2019; López et al., 2007). This Mitú Complex is itself a portion of the 1.86-1.55 Ga Rio Negro-Juruena Geochronological Province (Tassinari et al., 1996; Tassinari and Macambira, 1999). Older $(\sim 1.98 \mathrm{Ga})$ metavolcanic rocks of the Atabapo-Río Negro Gneiss may testify remains of the Trans-Amazonian basement (Kroonenberg, 2019) and not of the Mitú Complex accretion.

This complex was affected by several magmatic and tectonic episodes during the Mesoproterozoic (1.6-1.0 Ga), among them (in Colombia 1.40-1.34 Ga) intraplate A-type 
56 granite emplacements like the Parguaza and Matraca rapakivi granites (Bonilla et al., 2013;

57 Bonilla et al., 2016; Gaudette et al., 1978) and the Nickerie-K'Mudku thermal event 1.3-1.0

$58 \mathrm{Ga}$ ago deduced from far-reaching $\mathrm{K} / \mathrm{Ar}$ and $\mathrm{Rb} / \mathrm{Sr}$ ages resetting.

59

60 The youngest of the geochronological Amazonian Craton provinces identified hitherto is the

61 1.25-1.0 Ga old Sunsás Province (Error! Reference source not found.), a late

62 Mesoproterozoic collisional metamorphic belt in the southwestern margin of the Amazonian

63 Craton which constitutes an important paleogeographic link between the late Meso- and the

64 early Neoproterozoic, when Amazonia, Baltica and Laurentia became part of the Rodinia

65 supercontinent first proposed by Hoffman (1991) and confirmed by further studies (Cardona

66 et al., 2010; Cordani et al., 2010, 2009; Dewanckele et al., 2014). There is no reason why

67 younger accretionary belts, like the Rondonia-San Ignacio (1.55-1.3 Ma) and the Sunsás

68 (1.25-0.99 Ga) orogenic belts in the southern block, should not extend below the Amazon

69 Basin until the North Andean foreland. Covered by thick Cenozoic sediments (Cordani et al.,

70 2009; Santos et al., 2000; Tassinari and Macambira, 1999, 2004) and with dense tropical

71 forest and soils, their identification is difficult. However, several Grenvillian-age basement

72 inliers were identified in the northern Andes of Colombia (Figure 2), Ecuador and Peru (see

73 e.g. Restrepo-Pace and Cediel, 2010), although their lithostratigraphic and tectonic history

74 seem to differ somehow from that of the Sunsás belt. 


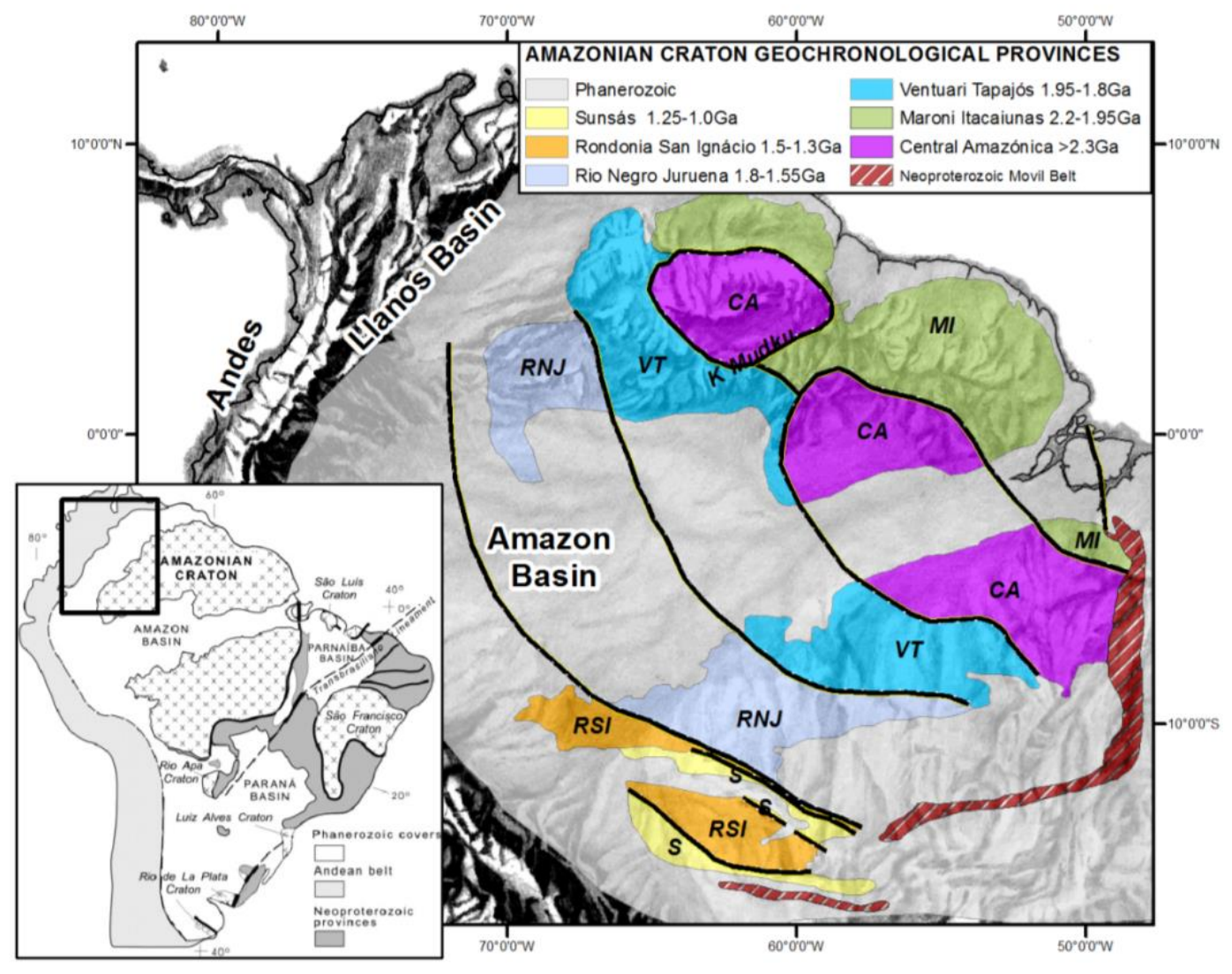

Figure 1 The Amazonian Craton in South America and Geochronological Provinces after Tassinari and Macambira (1999). CA: Central Amazonica, Ml: Maroni-Itacaiunas, VT:

78 Ventuari-Tapajos, RNJ: Rio Negro-Juruena, RSI: Rondonia-San Ignacio, S: Sunsás. The 79 extended Phanerozoic sediments W of the Andes as those filling the Llanos Basin cover large 80 parts of the Pre-Cenozoic rocks, and only small portions of Precambrian units like the Sunsás geochronological province the area of the (S) were identified hitherto in Colombia. 


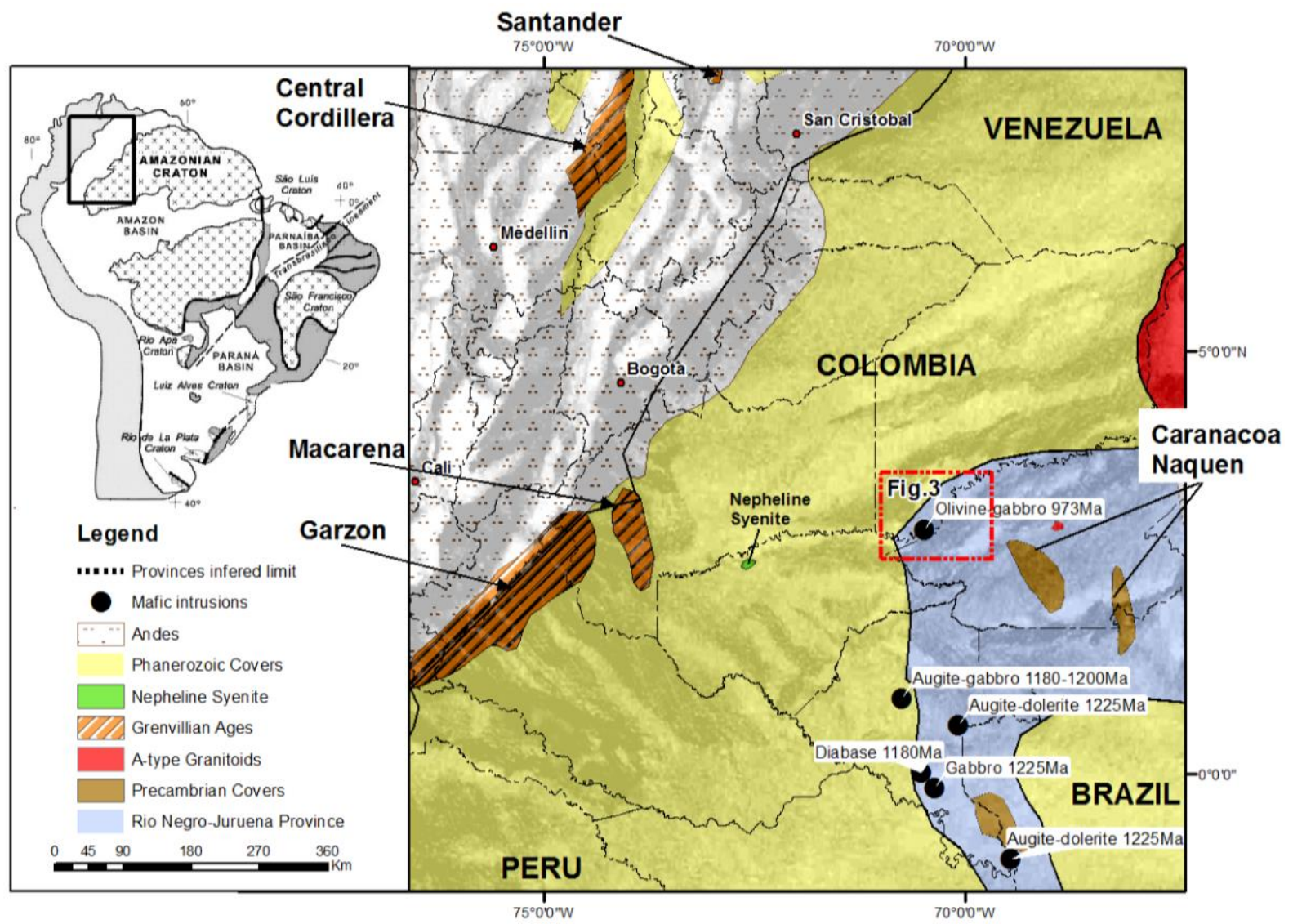

Figure 2 Location of the study area (red rectangle within the blue-marked Rio Negro-Juruena Province) in the Colombian part of the NW Amazonian Craton. Also shown are A-type granitoids to the East (Parguaza and Matraca rapakivi granites), Grenvillian-age remnants to the West near and within the Andes, the Ecarian to Cambrian Nepheline Syenite of San Jose de Guaviare, Precambrian (Caranacoa and Naquén) to Phanerozoic covers and ages of some mafic rock outcrops (Table 1). Modified after Cordani et al., 2010; Tassinari and Macambira, 1999; Ibañez et al., 2011, 2016; Bonilla et al., 2016.

Consequently, this belt could represent a separate composite orogeny (Cardona et al., 2010; Ibañez, 2010). Based on drill core sample analyses, Ibañez (2010) suggested the existence of a younger orogenic belt in Colombia called the "Putumayo Orogen" assumed to be coeval with the Sunsás belt. Both have a distinctly different posterior geological evolution, resulting, amongst others, in different structure and fabric. The Putumayo Orogen is marked by two evolutionary stages in a Rodinian context: i.e. an early tectonometamorphic event (1.05 Ga),

97 followed by anatectic melting $(1.01 \mathrm{Ga})$ resulting from an inferred arc-continent collision 
followed by a final continent-continent collision and associated granulite-facies metamorphism ( $\sim .99 \mathrm{Ga})$ (Ibañez et al., 2015; Ibañez, 2010). Relics of both events are found sporadically along the Colombian Andes as basement inliers (Figure 2) with U-Pb zircon ages of 1.1- 0.99 Ga (Cardona et al., 2010; Ibañez et al., 2015; Ibañez, 2010; Restrepo-Pace, 1995) possibly as product of a continent-continent collision (AmazoniaBaltica in this case) during the aggregation of the Mesoproterozoic supercontinent Rodinia, as first proposed by Hoffman (1991). Rivers (1997) suggested three orogenic pulses in the Canadian Grenville province, the Elzevirian (starting $\sim 1.35 \mathrm{Ga})$, Ottawan $(\sim 1.15 \mathrm{Ga})$ and Rigolet $(\sim 1.0 \mathrm{Ga})$. Only the last episode (Rigolet) has affected the entire magmatic-tectonic Grenville-province where indeed the Sunsás-belt acted as the Amazonia-Baltica counterpart of the Grenville belt on the Laurentia side during the collision that culminated in the final amalgamation of the Rodinia supercontinent.

Several intraplate rifting events have been recognized in the Amazonian Craton as responses to the collisions at its borders (Cordani et al., 2010; Santos et al., 2008; Teixeira et al., 2010). In the whole Rio Negro-Juruena Province, anorogenic granite intrusions with ages between 1.6-0.97 Ga are reported (Bettencourt et al., 1999; Bonilla et al., 2013; Dall'Agnol et al., 1999; Gaudette et al., 1978; Bonilla et al., 2016), whereas the less common mafic to ultramafic intrusive rocks yield $\mathrm{Rb}-\mathrm{Sr}$ and $\mathrm{K}-\mathrm{Ar}$ whole-rock isochron ages between 1.20-0.94 Ga (Priem et al., 1982; Tassinari et al., 1996; Teixeira and Tassinari, 1976). In the SW-Amazonian Craton some mafic rocks associated with a rift system as response to the Sunsás orogeny form part of a well-defined convergent active margin (Cordani et al., 2010; Santos et al., 2008; Teixeira et al., 2010). This indicates that while the western side of the Amazonian Craton (Amazonia) was colliding against Baltica and Laurentia to build Rodinia, expressing 
122 itself in the Grenvillian-Sunsás orogeny, rifting had already initiated further inland during the 123 Late Mesoproterozoic-Early Neoproterozoic (Cordani et al., 2010; Teixeira et al., 2010).

125 In this work, we show further evidence of Grenvillian-age mafic rift or intraplate magmatism in 126 the NW Amazonian Craton in Colombia based on petrographic, geochemical and U-Pb 127 apatite LA-ICP-MS analysis of the NW-SE trending ilmenite-apatite-rich Caño Viejita gabbro 128 in the SW-Vichada department some $500 \mathrm{~km}$ east of Bogota. Apatite fission-track 129 thermochronometry suggests furthermore a continuous exhumation and denudation process 130 of these rocks since the Jurassic until their current outcrop position.

\section{Geological and tectonic setting}

134 The Colombian part of the Amazonian Craton, which represents less than $10 \%$ of this 135 Precambrian nucleus in South America, outcrops in Vichada, Guainía, Vaupés, Caquetá and 136 Guaviare departments (Error! Reference source not found. and Figure 2) but is largely 137 covered by thick sedimentary sequences in the Amazonas and Llanos basins as weathering 138 and erosion products of its complex history.

139 140

\subsection{Eastern Colombian basement (1800-1500Ma)}

Since the 1960's, important progress has been made in the understanding of the geological evolution of this region which was initially simply named the Basement Group (Gansser, 1954). Especially different national remote sensing programs (e.g. Departamento Nacional da Producäo Mineral, 1976; Huguett, 1977; Kroonenberg and de Roever, 2010; PRORADAM, 1979; Putzer, 1984) and dedicated field work produced a wealth of new data. These studies have led in the $70_{\text {th }}$ to the recognition of the Mitú Migmatitic Complex (Galvis et al., 1979; Rodríguez et al., 2011), later called the Mitú Complex (Bonilla et al., 2019; López et al., 2007) 
149 Colombia (Tassinari et al., 1996; Tassinari and Macambira, 1999). Large parts of the Mitú

150 Complex (Figure 3) are composed of monzogranites with calc-alkaline characteristics, and 151 meta- to peraluminous affinity with an U-Pb LA-MC-ICPMS age for the Mitú granite of $1574 \pm$ 15210 Ma (Ibáñez-Mejía et al. 2011), as well as of other granites: Among the clearly 153 metamorphic rocks prevail quartzo-feldspathic gneisses with zircon $\mathrm{U}-\mathrm{Pb}$ ages between 154 1800-1760 Ma (Bonilla et al., 2019; Cordani et al., 2016; Kroonenberg, 2019; López et al., 155 2007). Medium grade amphibolite facies metamorphic rocks within a series of essentially 156 juvenile magmatic arcs in the Rio Negro Juruena province are interpreted as subduction157 related by several workers (Cordani et al., 2016; Tassinari and Macambira, 1999).

158 Younger granitoids in its SE-part (especially Guainia Department) exhibit variable 159 compositions, porphyritic textures and may contain ovoid feldspar phenocrysts that 160 crystallized some 1750 Ma ago during the Statherian (Bonilla et al., 2019).

161 On this Statherian basement, a metasedimentary sequence, associated with the Tunui Group 162 in Brazil (Almeida et al., 2004; Santos et al., 2003) was deposited about 1720 - 1600 Ma ago 163 (Bonilla et al., 2019) and extends to the north into the Naquen and Caranacoa mountains 164 (Figure 2). This Precambrian cover in the south of Guainia Department contains an upper 165 quartzite facies, partly tourmalinized, locally influenced by metasomatism which may be 166 responsible for gold deposits in this area and associated with a two-mica granite intrusion 167 some $1600-1550 \mathrm{Ma}$ ago (Bonilla et al., 2019). The latter is probably part of the Rio Içana 168 Intrusive Suite described in Brazil (Almeida et al., 2004; Almeida and Larizzatti, 1996; 169 Carneiro et al., 2017a, 2017b; Veras, 2012), and evolved by partial melting of cratonic 170 protoliths (Almeida et al., 1997). In a similar way, other $\sim 1600-1500$ Ma old granites have 
171 been described along the whole Colombian eastern territory (Cordani et al., 2016; Ibañez, 172 2010; Priem et al., 1982; Rodriguez et al., 2011).

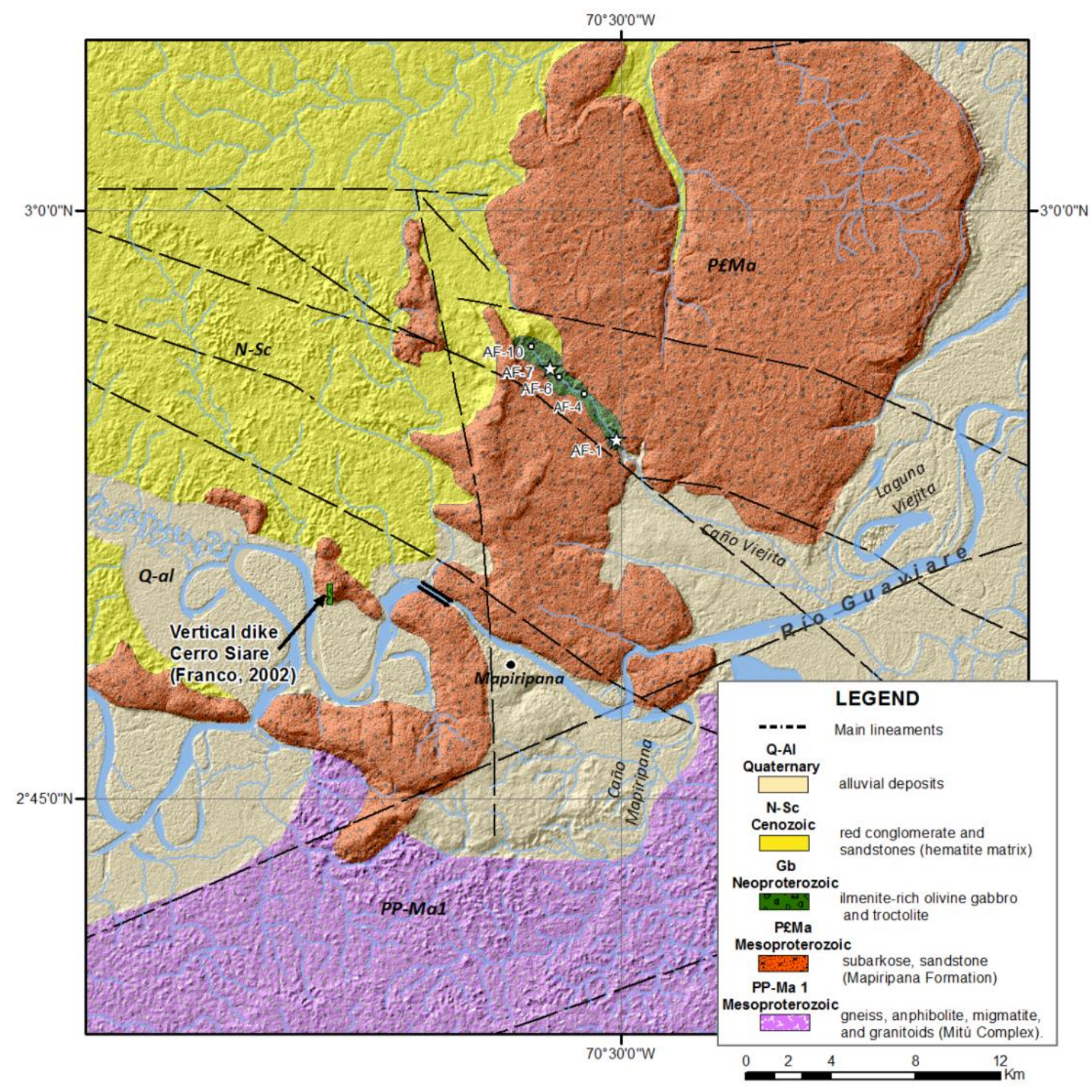

Figure 3 Geological map of the study area (red rectangle in Figure 2) with sampling points $\mathrm{AF}$ in the NW-trending gabbro surrounded by possibly Mesoproterozoic sedimentary rocks (modified from Franco et al., 2014; Franco et al., 2002; Gómez Tapias et al., 2015). Observe also the vertical gabbro dike at Cerro Siare crosscutting the sediments described by Franco et al. (2002).

\subsection{Anorogenic magmatism (1500-1000 Ma)}

Several rapakivi intrusive suites in the Brazilian SW-Amazonian Craton (e.g. Santo Antonio, 
183 Teotonio, Alto Candeias) represent extensional anorogenic magmatism associated with the 184 terminal stages of the Rondonian-San Ignacio Orogeny $\sim 1.50$ to $1.30 \mathrm{Ga}$ (Bettencourt et al., 185 1999). Also in the NW-part of the Rio Negro-Juruena Province in Colombia, evidence of rift or 186 intraplate magmatism exists, including $\sim 1.40$ to $1.34 \mathrm{Ga}$ rapakivi granite intrusions like the 187 Parguaza and Matraca rapakivi granites (Bonilla et al., 2013; Bonilla et al., 2016; Gaudette et 188 al., 1978). Later, the regional tectono-thermal "Nickerie-K'Mudku" event affected the area and 189 temperatures above $300^{\circ} \mathrm{C}$ resetted (partially) the $\mathrm{Rb}-\mathrm{Sr}$ and $\mathrm{K}-\mathrm{Ar}$ systems, leaving $1300-$ 1901000 Ma cooling ages (Cordani et al., 2016; Galvis et al., 1979; Priem et al., 1982).

191

192

193

194

195

196

197

198

199

200

201

202

203

204

205 206

Younger $<1.0 \mathrm{Ga}$ intra-plate A-type granites in the SW-Amazonian Craton (Teixeira et al., 2010) produced by extensional tectonics and rifting resulting from collisional events $\sim 1.25$ to 1.0 Ga (Teixeira et al., 2010) are until now unknown in the NW Amazonian Craton.

Less prominent than the felsic intrusions, but locally important, mafic intrusions and dikes occur in the Amazonian Craton, as for example on its western margin, where they are mainly of Grenvillian age (Error! Reference source not found.). Unfortunately, the current tropical climate and associated strong weathering reduce the number of outcrops for this rare rock types even more. Where they are visible, they cross-cut the basement or the overlying metasedimentary sequences along pre-existing major NE-SW or NW-SE trends forming dikes dated by $\mathrm{Rb} / \mathrm{Sr}$-whole-rock analyses between 1225-1100 Ma (Priem et al., 1982). Teixeira et al. (2010) describe mafic dikes, sills and graben basins as product of post-tectonic to anorogenic stages in the SW Amazonian Craton that took place after ca. $1 \mathrm{Ga}$.

Table 1 Mafic rocks of Grenvillian age reported in the NW and SW Amazonian Craton margin.

\begin{tabular}{|l|l|l|}
\hline Location and Rock type & Age (Ma) & Method and Reference \\
\hline NW Amazonian Craton & Rb/Sr whole rock, Priem (1982) Figure 2 \\
\hline $\begin{array}{l}\text { Papuri River: Augite- } \\
\text { dolerite }\end{array}$ & 1225 & \\
\hline
\end{tabular}




\begin{tabular}{|l|l|l|}
\hline $\begin{array}{l}\text { Serra Traira, NW Brazil: } \\
\text { Dolerite dikes }\end{array}$ & $940-980$ & $\mathrm{~K}-\mathrm{Ar}$, Tassinari (1996) \\
\hline $\begin{array}{l}\text { North of Manaus, } \\
\text { Amazonas: } \\
\text { intrusion }\end{array} \quad 1100$ & $\mathrm{~K}-\mathrm{Ar}$, Teixeira (1978); Tassinari (1996) \\
\hline $\begin{array}{l}\text { Pira-Parana River: } \\
\text { Diabase dike, }\end{array}$ & 1180 & $\mathrm{Rb} / \mathrm{Sr}$, whole rock Priem (1982) Figure 2 \\
\hline Augite-gabbro & 1200 & $\mathrm{Rb} / \mathrm{Sr}$ whole rock, Priem (1982) Figure 2 \\
\hline Augite-gabbro & 1180 & $\mathrm{Rb} / \mathrm{Sr}$ whole rock, Priem (1982) Figure 2 \\
\hline SW Amazonian Craton & $\begin{array}{l}\text { K-Ar + Rb-Sr Teixeira (1978), Tassinari } \\
(1996)\end{array}$ \\
\hline $\begin{array}{l}\text { Northern Rondonia State } \\
\text { of Brazil: dolerite dikes, } \\
\text { gabbros and alkaline } \\
\text { intrusions }\end{array}$ & $1050-$ & 1200 \\
\hline $\begin{array}{l}\text { Southern Rondonia State } \\
\text { of Brazil: dolerite dike } \\
\text { swarms }\end{array}$ & $\begin{array}{l}1000- \\
100\end{array}$ & $\mathrm{~K}-\mathrm{Ar}$ Teixeira (1978), Tassinari (1996) \\
\hline
\end{tabular}

\subsection{Post Mesoproterozoic events}

The youngest known intracratonic magmatic episode in the NW Amazonian Craton is a rift-

211 related alkaline subsiliceous event (Nepheline Syenite of San José del Guaviare) with

212 Neoproterozoic-Ediacaran to Cambrian ages (U-Pb zircon emplacement ages) of $\sim 578 \mathrm{Ma}$

213 (Mejia et al., 2012) and biotite K-Ar and Rb-Sr cooling ages of 445 - 495 Ma (Pinson et al.,

214 1962). Recent own LA-ICP-MS U-Pb zircon ages of 609 Ma (Franco et al., 2018; Muñoz

215 Rocha et al., 2019) near Jordan to the SE of the intrusion, suggest a long emplacement and

216 cooling history for this large body that is probably associated with the Pan-African - Braziliano

217 orogeny. Further west, no intracratonic intrusions are reported.

219 Since early Phanerozoic, predominant uplift and erosion of the NW Amazonian Craton are

220 evidenced by large stratigraphic hiatus, interrupted by several transgressions and marine 221 depositional regimes during the Paleozoic (e.g. Silurian (?) sandstone Araracuara Formation, 222 NW-trending Güejar- Apaporis Graben filled with marine platform and continental sediments). 
223 The Colombian Cretaceous Transgression, which extended at least to the modern Eastern

224 Cordillera at the western Amazonian Craton boundary, was the most prominent expression of

225 a Pre-Andean extension. It encompassed various back-arc zones with recognizable syn- and

226 post-rift phases of basin evolution (Horton, 2018) as result of an intensification of the Nazca

227 plate subduction below the incipient South American continent in its modern form. The related

228 rapid uplift, erosion and exhumation of the Amazonian Craton caused widespread Mesozoic

229 stratigraphic gaps all over the craton's cover and a high flux of recycled Precambrian sourced

230 sediments filling the Andes or Llanos Basin (Cardona et al., 2011) mainly in east - west

231 directed fluvial systems.

232

233 The Cenozoic Andean history shows a less pervasive extension in the midst of the Andean 234 orogeny and affected specific fore-arc lowlands, elevated hinterland regions, and isolated 235 retro-arc settings (Horton, 2018). Also, since the Paleogene, the Andean orogeny changed 236 the fluvial systems in the Colombian Amazonian Craton with its continental sedimentary cover 237 now directing the rivers eastwards to the Orinoco Basin or to the Amazonian Basin.

243 During a 2010 exploration survey in a black sands mining concession area (\#18557 mining 244 cadaster code), we found that the main ore minerals there were alluvial ilmenite concentrates 245 which obviously resulted from the weathering of a mafic intrusive body in the SW of the 246 Vichada Department. The source gabbro outcrops along a $6 \mathrm{~km}$ small creek called "Caño 247 Viejita", a tributary of the Guaviare River (Figure 3). The elongated gabbro trends N40W with 248 unclear extension, as to the north it is limited by a river and a $\sim 50 \mathrm{~m}$ thick sedimentary 
249 sequence that outcrops as "Tepui" with $<10^{\circ} \mathrm{N}$ dip, and is fringed by vertical cliffs (Figure 4A).

250 The tropical climate produced abundant spheroidal weathering forms (Figure 4B) and 251 yellowish weathering rims on the rock samples; it is not clear until which point abundant 252 secondary minerals like chlorite and serpentine are product of this weathering or syn- to 253 postmagmatic fluids. More field data are presented in the result and discussion chapters. 254 High ilmenite content visible in the fresh rock (Figure 4C) results in placer deposits as 255 weathering product of the gabbro. For this area, where presumably the ilmenites were mined 256 as titanium ore, also a mining license had been emitted years ago by the Colombian 257 authorities for wolframite, coltan and other alluvial "black sands" which served mainly for 258 "laundering" of wolframite and coltan illegally mined from other deposits in E-Colombia like 259 Cerro Tigre in the Guainía department. This illustration of the complex interaction between 260 geology, mining, lack of knowledge and both social, political and environmental issues 261 portrays the challenges of geologists in Colombia, but thanks to further exploration efforts of 262 the title owner in this case facilitated field recognition and sampling of black sands, soils and 263 fresh rocks which were brought to Bogotá for further analyses. 

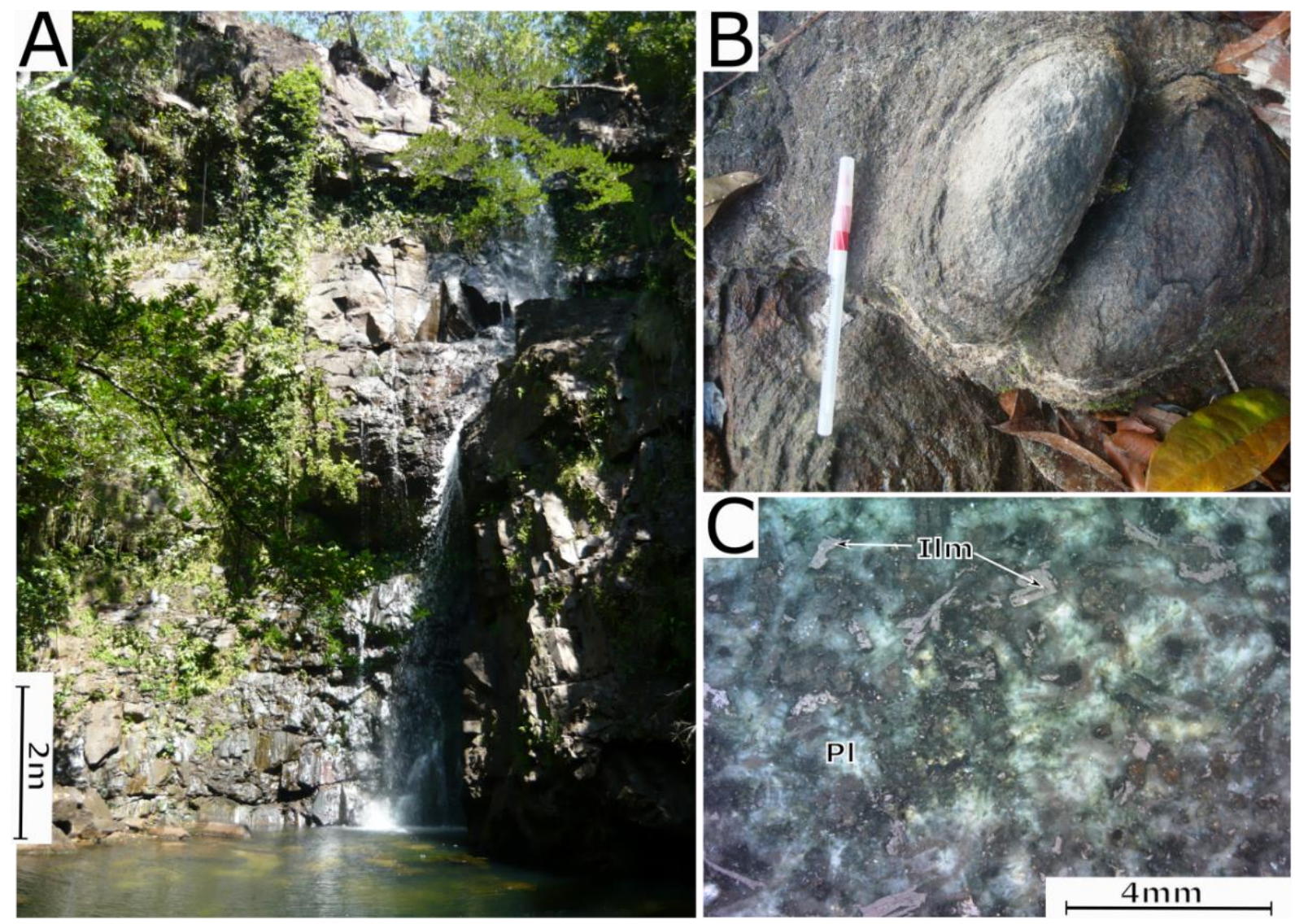

265

266

267

268

269

270

271

272

273 Seven thin sections from different parts of the gabbro were analyzed under a Zeiss Axio

274 Scope A1 petrographic microscope. Whole rock geochemistry by means of XRF was carried

275 out on 3 samples (Af-1, Af-7 and Af-4, the first two were also used for U-Pb apatite

276 geochronology, and sample Af-4 was measured one year later for quality control). The

277 samples were pulverized and mixed with Merck spectromelt wax at sample/wax ratio of 10/1

Figure 4 Some geological features in the study area: A) sub-horizontal layers of the Mesoproterozoic sedimentary sequence with characteristic waterfall of the Viejita creek with ilmenite concentrates; B) spheroidal forms resulting from tropical weathering of the gabbro; C) Binocular image (10x) of ilmenite crystals in plagioclase and pyroxene, within an undeformed gabbro texture.

\subsection{Petrography and whole rock geochemistry}

$$
\text { and measured with a Phillips MagixPro PW - } 2440 \text { X-ray fluorescence spectrometer (4 kW, }
$$

Rh-tube, reported detection limit $20 \mathrm{ppm}$ for heavy elements) at the National University of 
Colombia. For interpretation and diagrams, mainly the GCDkit5.0 software (Janousek et al., 2008) was used. By means of LA-ICP-MS, REE of extracted apatites were measured, which will be discussed later.

\subsection{Apatite U-Pb LA-ICP-MS geochronology}

Mineral separation procedures on two crushed gabbro samples (Af-1 and Af-7) at Universidade Federal do Rio Grande do Sul (Brazil) yielded too low datable zircon or baddeleyite contents in the concentrates, but sufficient apatite crystals of good quality after applying conventional mineral separation techniques. From the non-magnetic heavy fraction, apatite grains were carefully handpicked under a binocular microscope, embedded in epoxy resin and afterwards grounded and polished with a 6,3 and $1 \mu \mathrm{m}$ diamond suspension successively.

In the first sample (Af-1), apatite cathodoluminescence $(C L)$ images were acquired using a Reliotron CL system equipped with a digital color camera at Géosciences University Rennes, where also LA-ICP-MS U-Pb geochronology was conducted using an ESI NWR193UC Excimer laser coupled to a quadripole Agilent 7700x ICP-MS equipped with a dual pumping system to enhance sensitivity (Paquette et al., 2014). During the analyses, we used an ablation spot diameter of $50 \mu \mathrm{m}$, a repetition rate of $5 \mathrm{~Hz}$ and a fluence of $6.5 \mathrm{~J} / \mathrm{cm}^{2}$. Data were corrected for $\mathrm{U}-\mathrm{Pb}$ and $\mathrm{Th}-\mathrm{Pb}$ fractionation and for the mass bias by standard bracketing with repeated measurements of the Madagascar apatite standard (Cochrane et al., 2014). The apatite standards McClure (523.51 \pm 2.09 Ma (Schoene and Bowring, 2006)) and Durango (31.44 \pm 0.18Ma (McDowell et al., 2005)) which were used during the measurements to monitor precision and accuracy of the analyses, yielded ages of $520 \pm 9$ 
(McClure, $\mathrm{N}=3, \mathrm{MSWD}=0.47$ ) and $32.3 \pm 0.8 \mathrm{Ma}$ (Durango, $\mathrm{N}=5, \mathrm{MSWD}=0.76$ ). For instrumental conditions and protocols used in this study see Pochon et al. (2016) and Table 3.

A different protocol was necessary for the second apatite samples (Af-7), on which also fission track analysis were performed, as well as additional trace elements determinations (mainly $\mathrm{Cl}, \mathrm{Ca}, \mathrm{REE}$ ) using the same shots as for the U-Pb ages. The same LA-ICP-MS facility as described above was used, but with a spot size of $30 \mu \mathrm{m}$, a repetition rate of $7 \mathrm{~Hz}$ and a fluence of $6 \mathrm{~J} / \mathrm{cm}_{2}$. The full instrumental conditions and $\mathrm{U}-\mathrm{Pb}$ dating protocol are reported in Table 3, too. In the same way as the first sample, data were corrected for $\mathrm{U}-\mathrm{Pb}$ and $\mathrm{Th}-\mathrm{Pb}$ fractionation and for the mass bias by standard bracketing with repeated measurements of the Madagascar apatite standard (Cochrane et al., 2014). The same apatite standards as above used as secondary standard yielded a weighted mean $207 \mathrm{~Pb}$-corrected age of $528.9 \pm 7.0($ McClure, $\mathrm{N}=11, \mathrm{MSWD}=0.41)$ and $31.7 \pm 2.2 \mathrm{Ma}$ (Durango, $\mathrm{N}=24$ MSWD = 0.55)

\subsection{Apatite Fission Track Thermochronology and trace elements patterns}

The apatite fission track (AFT) method is a low-temperature thermochronological technique based on the spontaneous fission of $238 \mathrm{U}$ in the apatite crystal lattice. The fission decay produces lattice damage trails, the fission tracks, which can accumulate over time. At geological timescales, fission tracks in apatite are considered stable at temperatures lower than $\sim 60^{\circ} \mathrm{C}$, while they anneal completely at temperatures above $\sim 120^{\circ} \mathrm{C}$ (Ketcham et al., 1999; Wagner and Van den Haute, 1992). Between these two temperature thresholds, fission tracks (initially $\sim 16 \mu \mathrm{m}$ ) in apatite are gradually shortened, defining the Apatite Partial 
Annealing Zone (APAZ), which depends to some extent on the chemical composition of the apatite crystals (Wagner and Van den Haute, 1992). With a minimum of $\sim 100$ measured confined fission track lengths, it is statistically viable to model or reconstruct the lowtemperature thermal history of the apatite-bearing rock sample (e.g. Ketcham et al., 1999), but 40 track lengths are considered the absolute minimum (Rahn and Seward, 2000). If significantly less than 100 confined tracks could be measured, only a qualitative (and rather speculative) model can be retrieved, and interpretation of the AFT data and accompanied time-temperature model has to be done with care.

Fission tracks were counted on 800x magnification with a Nikon Eclipse NI-E microscope system and imaged with a DS-Ri2 camera attached to the microscope system. The determination of the uranium concentration for fission track dating followed the analytical protocol of Cogné et al. (2019). In contrast to the LA-ICP-MS absolute calibration approach of Hasebe et al. (2004), which employs the $238 \mathrm{U}$ fission-decay constant, a fission-track registration factor and a calibration factor for etching and observation, Cogné et al. (2019) used a modified zeta calibration approach (cf. Hurford and Green, 1983) for LA-ICP-MS apatite $U$ concentration measurements, building on Donelick et al. (2005). The method assumes that the apatite ${ }_{43} \mathrm{Ca}$ signal intensity during a given LA-ICP-MS session acts as a proxy for the volume of apatite ablated, and hence the apatite ${ }_{238} \mathrm{U} / 43 \mathrm{Ca}$ ratio yields relative $\mathrm{U}$ concentration measurements. In this study, an extensive primary LA-ICP-MS session was

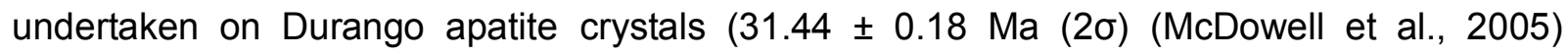
previously counted for fission tracks to yield a primary LA-ICP-MS zeta factor. The uncertainty on the calibration procedure (including the age uncertainty and the counting statistics related to the number of spontaneous tracks counted in the Durango standard) was propagated through to the final zeta calculation. These same Durango apatite crystals were 
then analyzed in subsequent LA-ICP-MS (along with apatite unknowns for fission-track dating) to yield a session-specific calibration factor on the primary zeta value. Inter-session drift in both the primary and subsequent LA-ICP-MS sessions was corrected for by monitoring the ${ }_{238} \mathrm{U} / 43 \mathrm{Ca}$ ratio of NIST612 standard glass. Depth-related variations in $\mathrm{U}$ concentration were accounted for by incorporating a function within the lolite "Trace elements" data reduction scheme that weights appropriately the ${ }_{238} \mathrm{U} / 43 \mathrm{Ca}$ ratio with depth. Chlorine measurements are calibrated with a synthetic "Bamble" apatite (e.g. Chew et al. 2016).

Data reduction for trace-element data acquired on the same spots was undertaken using the freeware lolite package of Paton et al. (2011), with the "Trace Elements" data reduction scheme. NIST612 was used as primary reference material. Cl concentration measurements followed the analytical protocol of Chew et al. (2016). The ${ }_{35} \mathrm{Cl}$ background-corrected signals for each apatite analysis were normalized to the internal standard $\left({ }_{43} \mathrm{Ca}\right)$ and then samplestandard bracketing was employed using synthetic apatites of known $\mathrm{Cl}$ concentration (chlorapatite end member $6.81 \mathrm{wt} \% \mathrm{Cl}$, (Klemme et al., 2013)) and Durango fluorapatite (0.37 wt\% Cl).

\subsection{Petrological and geochemical results}

As the N40W trending gabbro body (Figure 3) is covered to the north by thick sedimentary sequences, its real extent is difficult to assess. The vertical cliffs (Figure 4A) with abundant spheroidal weathering forms (Figure 4B) as well as the high ilmenite content in the fresh rock (Figure 4C) and alluvial "black sands" allow to assume that the body is rather large and affected by active (at least until recently) uplift processes. The continuous supergenic 
381 processes are evidenced in the yellowish weathering rims, secondary chloritization and

382 abundant serpentine, although the contribution of syn- or postmagmatic hydrothermal fluids is 383 not clear, and no signs of metamorphic remobilization are visible, neither macro nor 384 microscopically, nor geochemically.
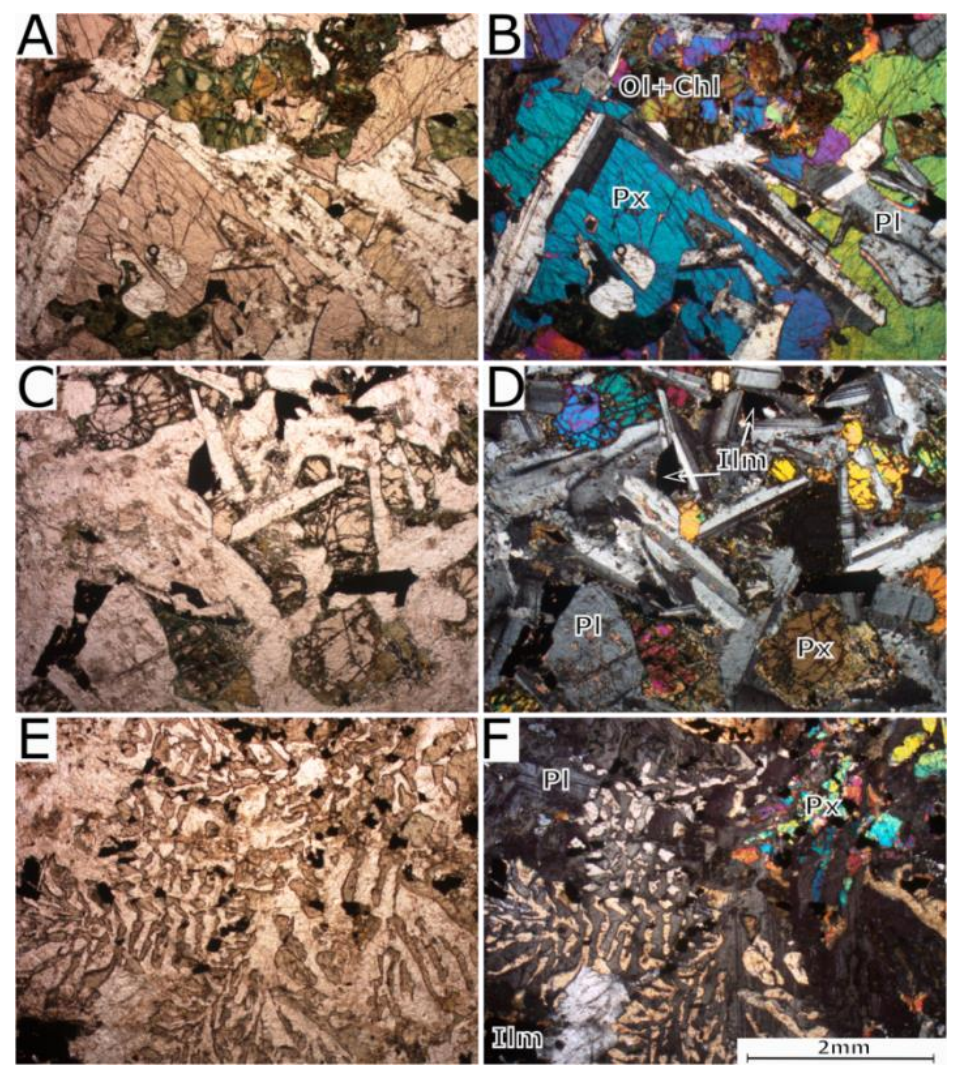

386

387

388

389

390
Figure 5 Thin-sections micro-photographs of gabbro samples from Caño Viejita, right side crossed nicols. A-B) olivine-gabbro with interstitial texture showing plagioclase, pyroxene and olivine crystals altered to chlorite; C-D) gabbro with intergranular texture, abundant ilmenite and pyroxene partially altered to chlorite; E-F) gabbro with poikilitic texture where pyroxene laths are enclosed by plagioclase. 

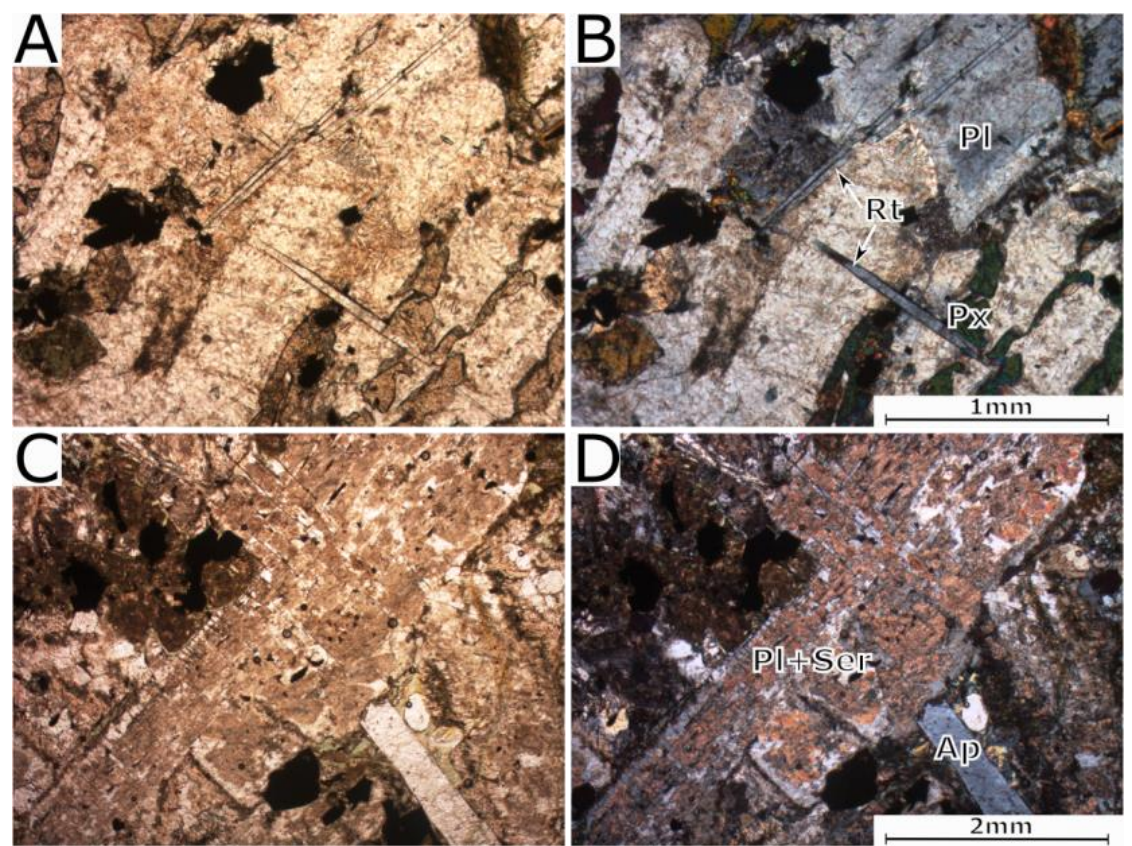

392

393

394

395

396

Figure 6 Thin-sections micro-photographs (right XPL) of gabbro samples from Viejita creek, A-B) plagioclase and pyroxene, traversed by acicular rutile crystals; C-D) pronounced replacement of plagioclase by sericite and of olivine by serpentine + chlorite. Observe large apatite crystals and, in both sections, abundant opaque ilmenite grains. 
Petrographically, the rock is a gabbro to olivine-gabbro with $58-67 \%$ plagioclase (An70), 713\% clinopyroxene and $4-10 \%$ olivine. Abundant accessory minerals $(\sim 12 \%)$ are ilmenite, rutile, large apatite crystals and pyrite. Neither enough baddeleyite nor zircon were identified for geochronology analyses, thus testifying Si-subsaturation and low Zr-contents (but see note below). Parts of the gabbro exhibit poikilitic texture where large plagioclase phenocrysts enclose skeletal pyroxene crystals (Figure 5E-F) while other portions show interstitial and intergranular textures. Fe-rich olivine (fayalite) is identified due to its slightly higher relief than pyroxene, as well as its fracturing and alteration products like chlorite and serpentine visible in some parts, whereas in the prevailing pyroxenes chlorite alteration dominates. Other alteration minerals are sericite, epidote and iron oxides, as in sample Af-1. Some $\sim 1 \%$ biotite in samples Af-6 and Af-7 are associated with ilmenite or pyrite surrounding some olivine crystals. Titanite traces were found in sample Af-1.

XRF data for major and some trace elements are shown in Table 2, together with continental crust gabbro (CCG) values after Le Maitre (1976), cited in Wedepohl (1995) and "normal" gabbro after Nockolds (1954, cited in Perkins, 2014). The geochemistry of the three samples is rather similar, suggesting that they are part of a homogeneous body. The $\mathrm{SiO}_{2}$ content varies from $46.46 \%$ to $48.15 \%$, which is in the range of a normal gabbros, although with some Si-subsaturation (cf. e.g. https://earthref.org/GERMRD/). High $\mathrm{Fe}_{2} \mathrm{O}_{3}(\sim 13 \%)$ reflects itself in fayalite, Fe-pyroxene and, together with high $\mathrm{TiO}_{2}$ content from $3.12 \%$ to $3.43 \%$, in abundant ilmenite and much less rutile in the gabbro. While $\mathrm{Al}_{2} \mathrm{O}_{3}$ content from $15.55 \%$ to $15.83 \%$ is typical, $\mathrm{K}_{2} \mathrm{O}$ content from $1.86 \%$ to $2.04 \%$ is rather high for a normal gabbro, thus nearly reaching shoshonite composition, although no K-main minerals were found. On the other hand, $\mathrm{CaO}$ from $7.36 \%$ to $8.24 \%$ and $\mathrm{MgO}$ from $4.27 \%$ to $4.99 \%$ are lower than in oceanic-crust associated gabbro, but $\mathrm{CaO}$ is higher than in $\mathrm{CCG}$. High $\mathrm{P}_{2} \mathrm{O}_{5}$ from 1.54-1.72\% 
422 expresses itself in abundant apatite, whereas the low Zr-contents together with Si423 subsaturation did virtually not allow zircon crystals to form, although the surely not very 424 precise XRF Zr-values (Table 2) are apparently above the $140 \mathrm{ppm} \mathrm{Zr}$ reported for basalts 425 and also a lot of granitic rocks (e.g. Mielke, 1979). Geochemical-petrotectonic discrimination 426 patterns (Error! Reference source not found.) such as $\mathrm{Na}_{2} \mathrm{O}+\mathrm{K}_{2} \mathrm{O}$ vs. $\mathrm{SiO}_{2}$ (Cox et al., 427 1979), $\mathrm{MgO}-\mathrm{FeO}-\mathrm{Al}_{2} \mathrm{O}_{3}$ (Pearce et al., 1977) and $\mathrm{TiO}_{2}-\mathrm{K}_{2} \mathrm{O}-\mathrm{P}_{2} \mathrm{O}_{5}$ (Pearce et al., 1975) 428 locate this intrusive in the field of continental alkaline metaluminous gabbro of Within-Plate 429 characteristics based on the $\mathrm{Zr}-\mathrm{Y}$ relationship (Pearce and Norry, 1979). Low content together with XRF-detection limits and deficient precision did not allow using other common trace elements like $\mathrm{Nb}$, Ta or most REE for further confident geotectonic interpretations of the 432 gabbro samples.

Table 2 XRF geochemistry of gabbro samples AF-1, AF-4 and AF-7 and of Continental Crust Gabbro (CCG) after Wedepohl (1995, citing Le Maitre (1976)) and "normal" gabbro after Nockolds (1954, cited in Perkins, 2014). Observe the lower $\mathrm{SiO}_{2}$ and $\mathrm{MgO}$ but much higher $\mathrm{Na}_{2} \mathrm{O}, \mathrm{TiO}_{2}, \mathrm{~K}_{2} \mathrm{O}$ and $\mathrm{P}_{2} \mathrm{O}_{5}$ contents in comparison with $\mathrm{CCG}$ and "normal" gabbro, which express in minerals like rutile, and abundant ilmenite and apatite. Only $\mathrm{CaO}$ lies between the 438 two gabbro types, possibly reflecting the anorthosite component. Oxides reported in wt.\% and 439 trace elements in ppm.

\begin{tabular}{|c|r|r|r|r|r|}
\hline Element & \multicolumn{1}{|c|}{ Af 1 } & \multicolumn{1}{|c|}{ Af 4 } & \multicolumn{1}{c|}{ Af 7 } & \multicolumn{1}{c|}{ Gabbro } & \multicolumn{1}{c|}{$\begin{array}{c}\text { Gackolds } \\
\text { (1954) }\end{array}$} \\
\hline $\mathrm{SiO}_{2}$ & 48.152 & 46.46 & 47.854 & 50.1 & 50.78 \\
\hline $\mathrm{Al}_{2} \mathrm{O}_{3}$ & 15.833 & 15.72 & 15.551 & 15.5 & 15.68 \\
\hline $\mathrm{Fe}_{2} \mathrm{O}_{3} \mathrm{incl} . \mathrm{FeO}$ & 13.074 & 13.82 & 12.746 & 11.5 & 2.26 \\
\hline $\mathrm{FeO}$ & & & & & 7.41 \\
\hline $\mathrm{CaO}$ & 7.395 & 7.36 & 8.245 & 4.58 & 10.85 \\
\hline $\mathrm{MgO}$ & 4.455 & 4.99 & 4.279 & 7.6 & 8.35 \\
\hline $\mathrm{Na} 2 \mathrm{O}$ & 3.831 & 3.85 & 3.696 & 2.4 & 2.14 \\
\hline $\mathrm{TiO}_{2}$ & 3.122 & 3.42 & 3.431 & 1.1 & 0.81 \\
\hline $\mathrm{K}_{2} \mathrm{O}$ & 2.045 & 1.86 & 1.897 & 0.9 & 0.56 \\
\hline $\mathrm{P}_{2} \mathrm{O}$ & 1.541 & 1.70 & 1.720 & 0.24 & 0.05 \\
\hline $\mathrm{MnO}$ & 0.156 & 0.18 & 0.172 & 0.12 & 0.18 \\
\hline
\end{tabular}




\begin{tabular}{|c|c|c|c|c|}
\hline $\mathrm{H}_{2} \mathrm{O}$ & & & & 0.76 \\
\hline $\mathrm{Ba}$ & 1050 & 1700 & 840 & \\
\hline $\mathrm{Sr}$ & 790 & 740 & 800 & \\
\hline $\mathrm{Cl}$ & 560 & 1030 & 1200 & \\
\hline$S$ & 480 & 590 & 1400 & \\
\hline v & 0 & 0 & 500 & \\
\hline $\mathrm{Ce}$ & 390 & 380 & 200 & \\
\hline $\mathrm{Zr}$ & 300 & 270 & 400 & \\
\hline $\mathrm{Zn}$ & 170 & 130 & 200 & \\
\hline $\mathrm{Cr}$ & 90 & 0 & 0 & \\
\hline $\mathbf{R b}$ & 50 & 70 & 44 & \\
\hline$Y$ & 50 & 40 & 38 & \\
\hline $\mathrm{Nb}$ & 0 & 0 & 25 & \\
\hline
\end{tabular}
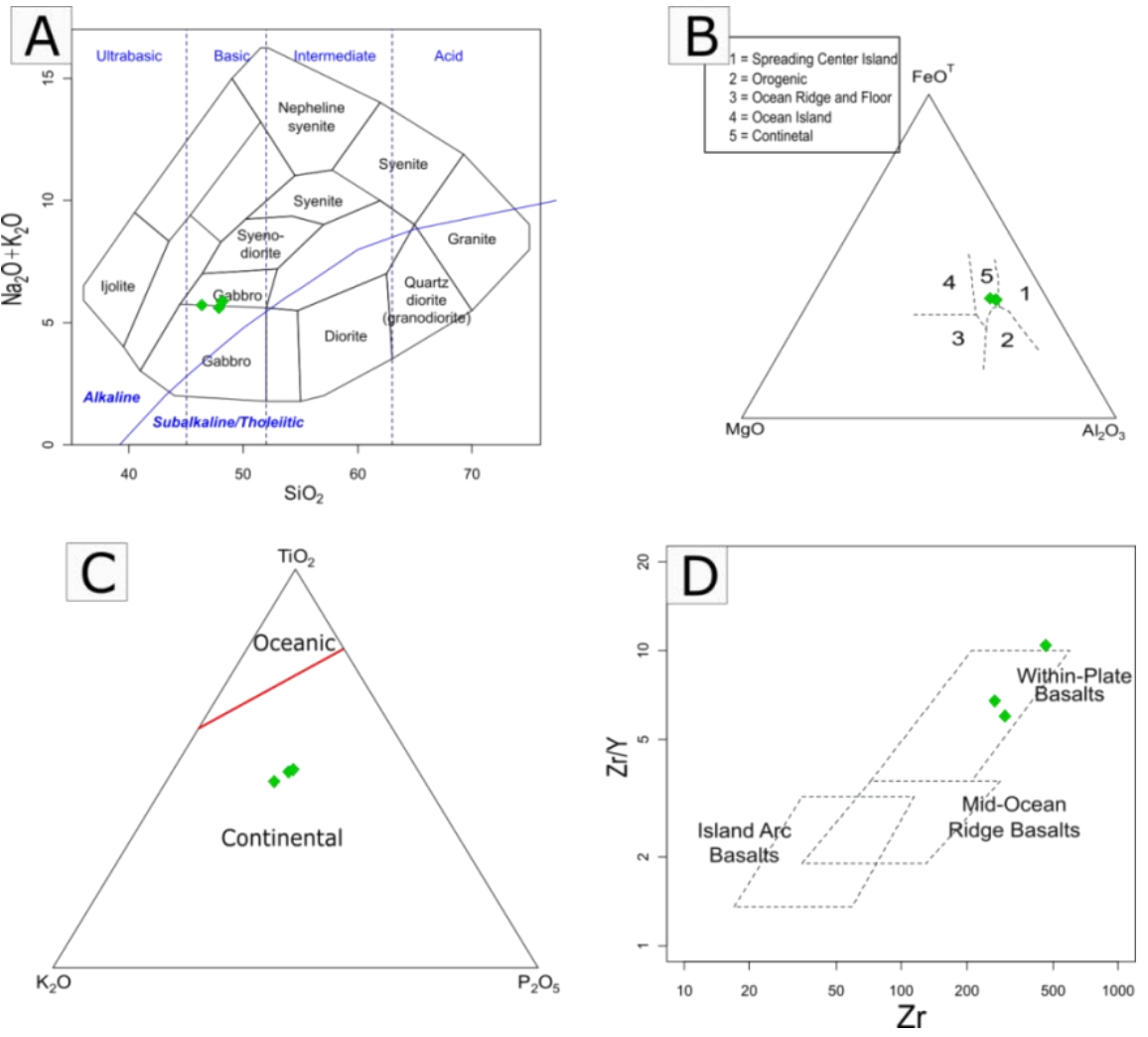

Figure 7 Gabbro samples plotted in A) $\mathrm{Na}_{2} \mathrm{O}+\mathrm{K}_{2} \mathrm{O}$ vs $\mathrm{SiO}_{2}$ diagram after Cox et al. (1979); B) MgO-FeOт- $\mathrm{Al}_{2} \mathrm{O}_{3}$ after Pearce et al. (1977); C) $\mathrm{TiO}_{2}-\mathrm{K}_{2} \mathrm{O}-\mathrm{P}_{2} \mathrm{O}_{5}$ after Pearce et al. (1975); D) $\mathrm{Zr} / \mathrm{Y}$ vs Zr for basalts after Pearce and Norry (1979). 
Apatites are versatile geological materials not only useful for geochronological and thermal 447 evolution studies as below but also, for example, to decipher magma-fluid interactions and 448 differentiation (e.g. Harlov 2015). Cl-normalized (Anders and Grevesse,1989) Rare Earth 449 Elements values of the 35 apatite crystals from the Caño Viejita gabbro sample Af-7 (Error! 450 Reference source not found.) analyzed by means of LA-ICP-MS during the U-Pb dating 451 show a strong enrichment mainly of the LREE with a decreasing slope to heavier REE $452\left((\mathrm{Ce} / \mathrm{Yb})_{\mathrm{cn}}\right.$ of $\left.\left.12-13\right)\right)$ and a moderate negative Eu-anomaly $(2 \mathrm{Eu} /(\mathrm{Sm}+\mathrm{Gd}))_{\mathrm{cn}}$ of $\left.0.62-0.7\right)$, 453 common patterns observed in many apatites. The latter was probably controlled by former or 454 simultaneous plagioclase crystallization (e.g. Rollinson, 1993) much more than the own 455 apatite redox-state. REE-distribution patterns at first glance are similar to apatites from 456 syenites and associated jacupirangites reported by Belousova et al. (2002). However, other 457 parameters differ, like the lower sum of REE between 0.2-0.6wt.\%. A slight positive Ce458 anomaly (2Ce/La+Pr)cn of 1.1-1.2, Y 328-934ppm, Mn 358-478ppm, Sr 516-747ppm, Th 2.4459 6.3ppm, $\mathrm{U}$ from 1.1-2.25ppm and mainly radiogenic $\mathrm{Pb}$ from 2-8ppm with rather high ${ }_{204} \mathrm{~Pb}$ 460 give some clues about the apatite and gabbro crystallization process, using for example the 461 discrimination patterns proposed by Belousova et al. (2002). The $\mathrm{Sr} / \mathrm{Y}$ values (Sr 516462 747ppm / Y 328-934ppm) occupy the granitoid but more the mafic rocks to Fe-ore fields of 463 Belousova et al. (2002). (Ce/Yb) cn of 12-13 and Sum REE 0.2-0.6 wt.\% are in the granitoid 464 and near the dolerite field. Sr 516-747ppm/ Mn 358-478ppm correlations are in the larvikites, 465 jacupirangite and iron ore fields, $Y$ 328-934ppm/ Eu/Eu* 62-0.7 occupy the granitoids, mafic 466 rocks and iron ore fields. The absence of observable concurrent phosphate minerals 467 (monazite or xenotime) or garnets which tend to scavenge REE and other incompatible 468 elements as well of zircons explain a good part of this behavior. 
469 Thus, both the apatite as the gabbro characteristics hint to a somehow enriched gabbro 470 mantle source.

471

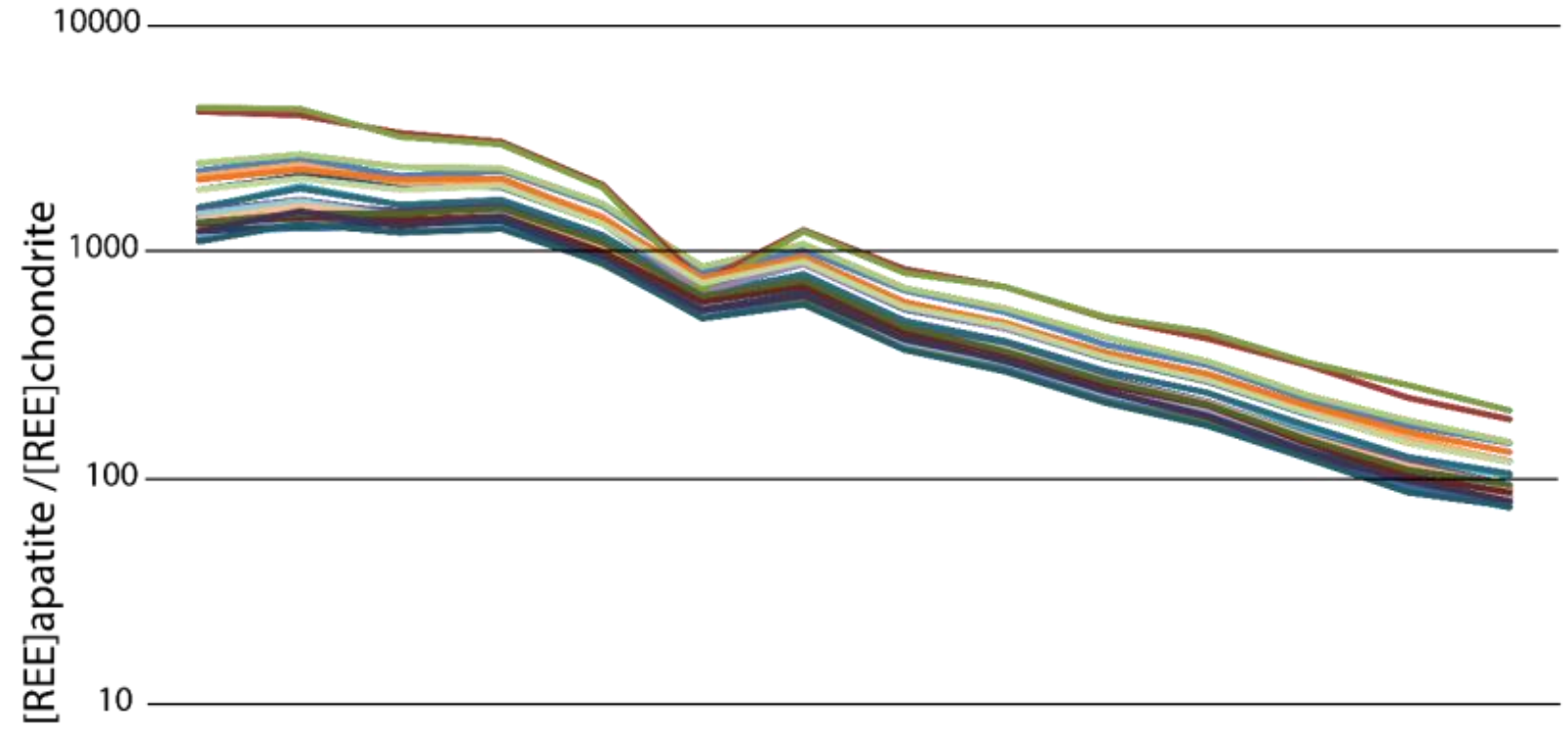




\section{Th vs. Ce in apatites}

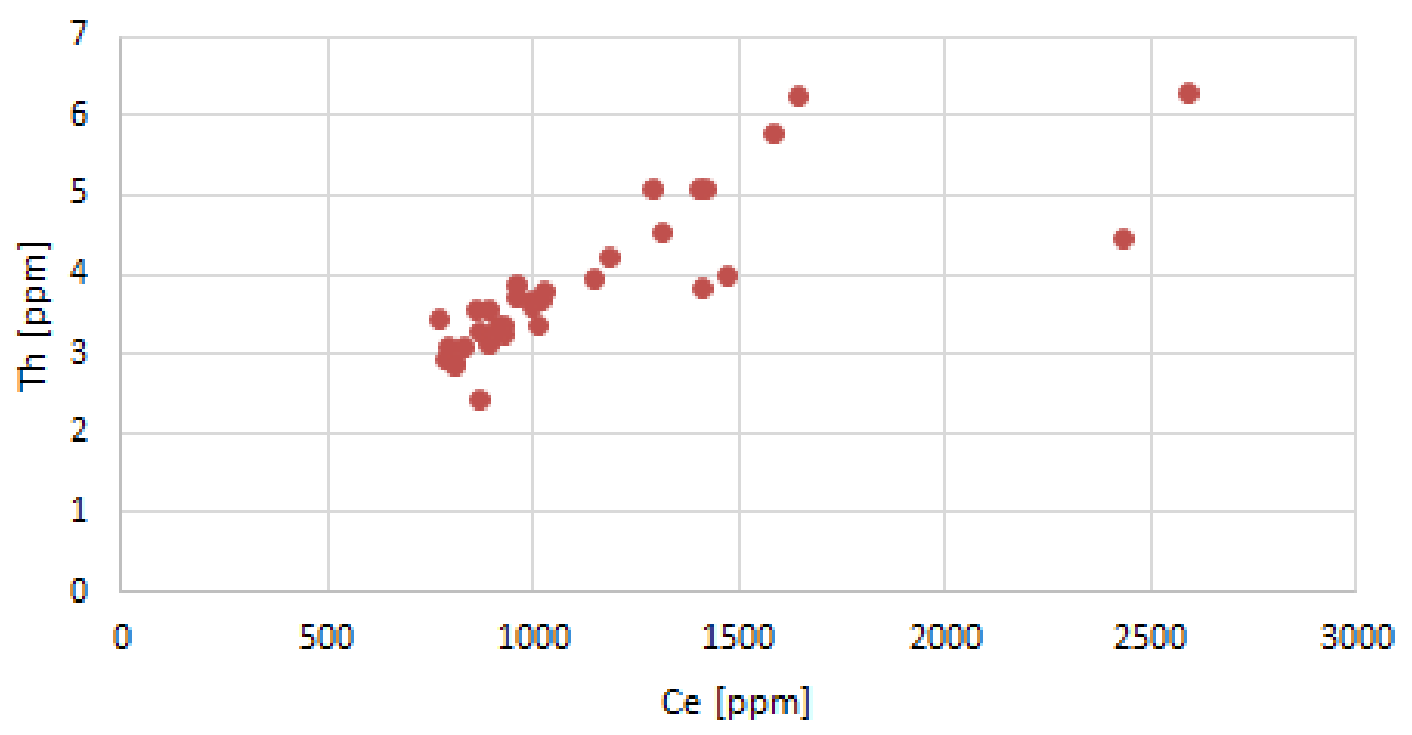

474 Figure 8A Cl-normalized (Anders and Grevesse, 1989 in McDonough and Sun, 1995) REE 475 contents of 35 apatite crystals from Caño Viejita gabbro sample Af-7 showing strong 476 enrichment mainly of LREE with nearly log-linear decrease tendency of heavier REE and a 477 moderate negative Eu-anomaly. B: Positive correlation Th vs. Ce in the apatite samples. 


\subsection{Apatite U-Pb and FT geochronology}

As zircon and baddeleyite contents in the gabbro samples are very low and only a few zircon grains were found in thin sections mainly as inclusions inside ilmenite or at the boundary between plagioclase and pyroxene grains, not sufficient material could be obtained for $\mathrm{U}-\mathrm{Pb}$ geochronology in neither of the Zr-minerals. However, the high amount of good-quality apatite grains allowed applying apatite $\mathrm{U}-\mathrm{Pb}$ dating. Two samples (Af-1 and Af-7) with large and abundant apatite grains, which exhibit perfect euhedral prism shapes and grain sizes between 100 to $500 \mu \mathrm{m}$ were selected using binocular, petrological microscope and CLimaging. CL-images of sample Af-1 exhibit yellow-grayish luminescence free of visible internal structures like cores or zoning (Figure 9).

The U-Pb data of twenty-five apatite grains from this sample Af-1 (Table 4) plotted in a TeraWasserburg diagram (Figure 10) show discordant ages with a rather high proportion of common (non-radiogenic) $\mathrm{Pb}$ and $207 \mathrm{~Pb} / 206 \mathrm{~Pb}$ ratios between 0.38 and 0.49 . They yield a

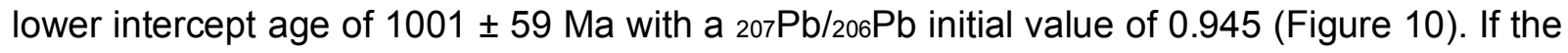
discordia is forced to a ${ }_{207} \mathrm{~Pb} / 206 \mathrm{~Pb}$ value of $0.909 \pm 0.004$, calculated for an age of $1000 \pm 50$ Ma following the $\mathrm{Pb}$ evolution model of Stacey and Kramers (1975), we obtain a similar age, although with lower scattering, of $975 \pm 9$ Ma (MSWD=0.95) (Figure 10). The weighted average ${ }_{207} \mathrm{~Pb}$-corrected date is in agreement at $979 \pm 10 \mathrm{Ma}$ (Figure 10). 


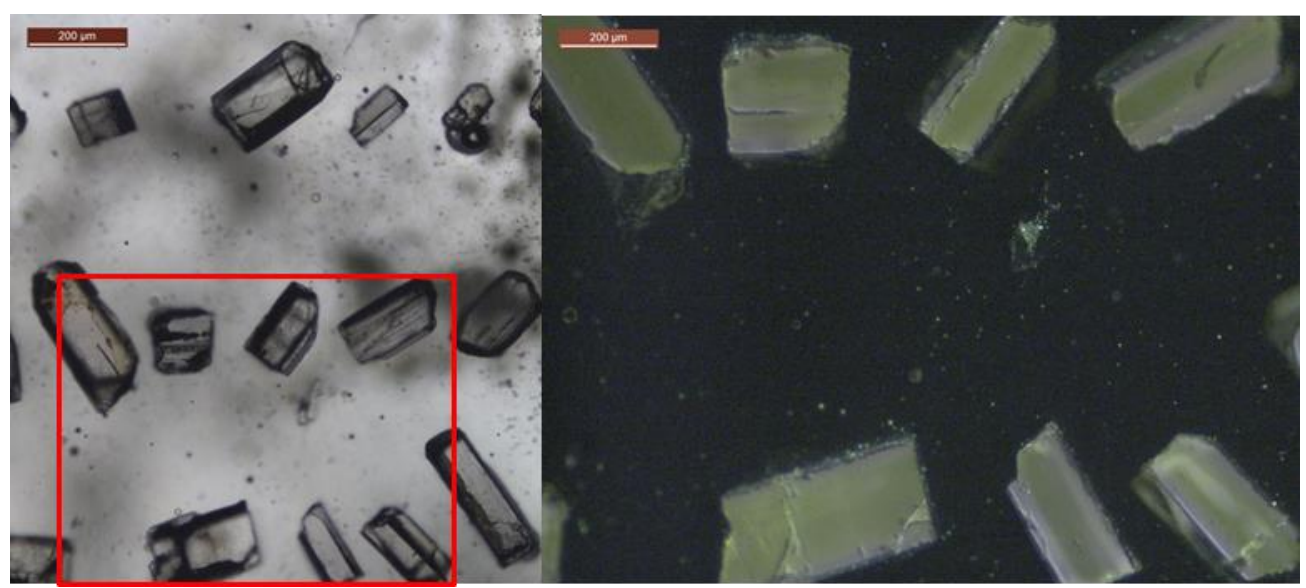

498 Figure 9 Embedded apatite crystals under the transmitted light microscope (left) and 499 magnified CL-images from Af-1 showing homogeneous yellow-grayish luminescence (right).

$501 \mathrm{U}-\mathrm{Pb}$ data of the 35 apatite grains from the second sample (Af-7 in Table 4) yield a lower 502 intercept age of $961 \pm 61 \mathrm{Ma}$ with a $207 \mathrm{~Pb} / 206 \mathrm{~Pb}$ of 0.864 (Figure 10). The forced regression 503 with an initial common $\mathrm{Pb}$ value of $0.909 \pm 0.004$ yield an age of $1002 \pm 21 \mathrm{Ma}$ (Figure 10) 504 coherent with the weighted mean $207 \mathrm{~Pb}$-corrected age of $1034 \pm 26 \mathrm{Ma}$ (Figure 10). 505 Therefore, the unforced age is coherent with the lower intercept and the corrected age of Af-1 506 sample. The corrected age (based on Stacey and Kramers 1975 single evolution model) of $5071034 \pm 26 \mathrm{Ma}$ is the oldest of all obtained ages. In spite of the scatter, both samples share a 508 common history. 

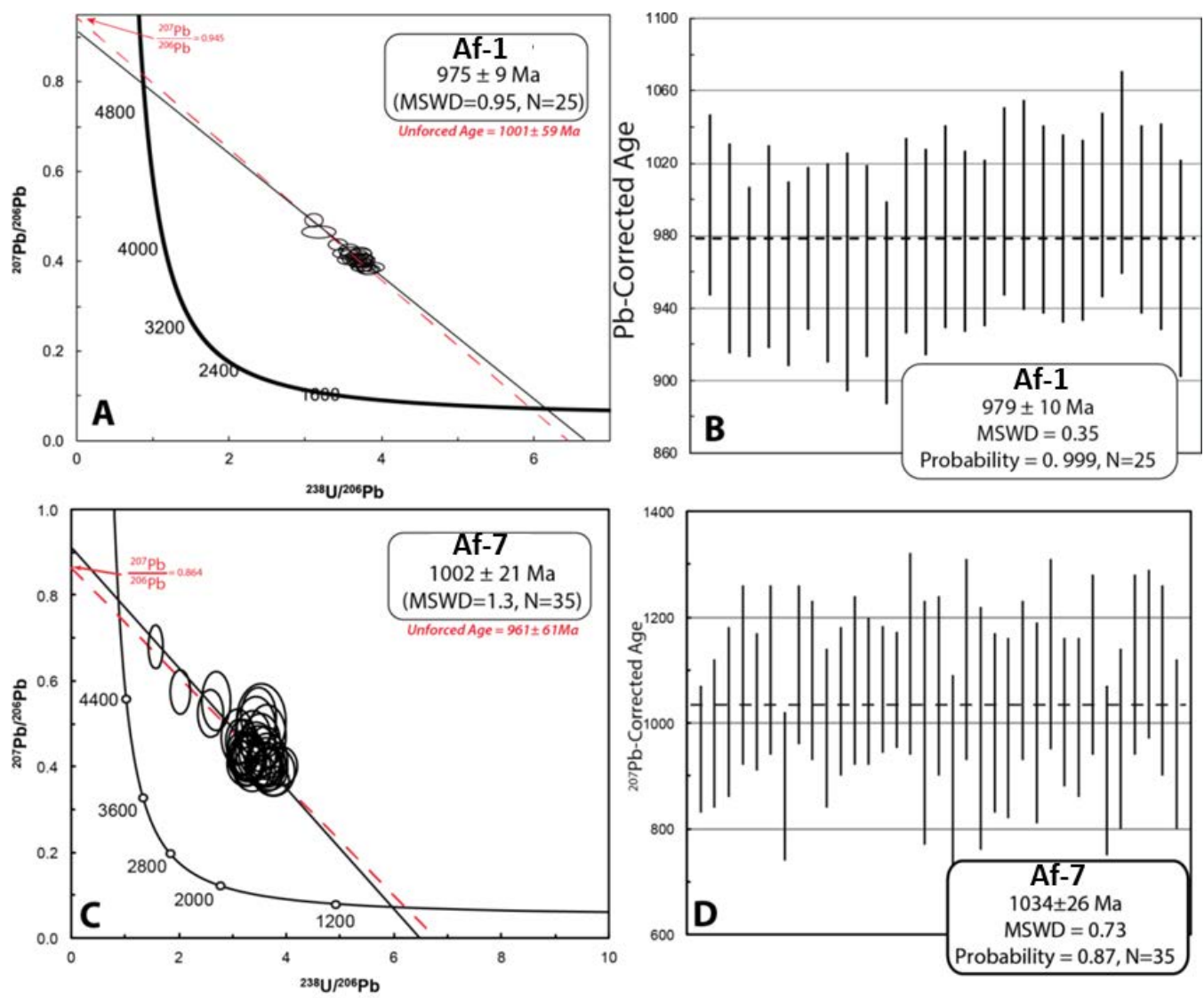

Figure 10 Tera-Wasserburg Concordia diagrams and weighted average $207 \mathrm{~Pb}$-corrected ages for the 25 single apatite grains from olivine gabbro sample Af-1 $(A+B)$ and 35 single grains from gabbro Af-7 (C+D).

512

513

514 A Lower Jurassic (Toarcian) AFT central age of $179.8 \pm 9.0$ Ma (Figure 11A) based on 33

515 grain analysis could be calculated (Table 4, Figure 11). The chlorine content for the gabbro

516 apatite is $0.28 \pm 0.13 \mathrm{wt} \%$, and single grain ages are not related to $\mathrm{Cl}$-content (Figure 11).

517 The spontaneous fission track density is rather low, and only 47 horizontal confined tracks

518 could be measured. The mean track length from this limited data set is short at $11.8 \mu \mathrm{m}$, with

519 a large standard deviation of $1.9 \mu \mathrm{m}$. An attempt for a thermal history reconstruction must

520 consider that it is based on an absolute minimum of track length information. C-axis

521 projection (Ketcham et al., 2007) of the apatite fission tracks was performed because the data

522 showed anisotropic annealing and follows the model of Donelick et al. (1999) (Figure 11B) 
523 and give a narrower distribution with a c-axis-projected mean length of $13.5 \mu \mathrm{m}$.

524 Subsequently, the C-axis-projected length data and the compositional data (i.e. the chlorine-

525 content) were modelled (Figure 11C) with the QTQt software (v5.6.0) (Gallagher, 2012),

526 according to the strategies reported in Van Ranst et al. (2019). After c-axis projection, the

527 mean track length of the sample increased from 11.8 to $13.5 \mu \mathrm{m}$ and the distribution of the

528 track length histogram was much narrower (Figure 11D).
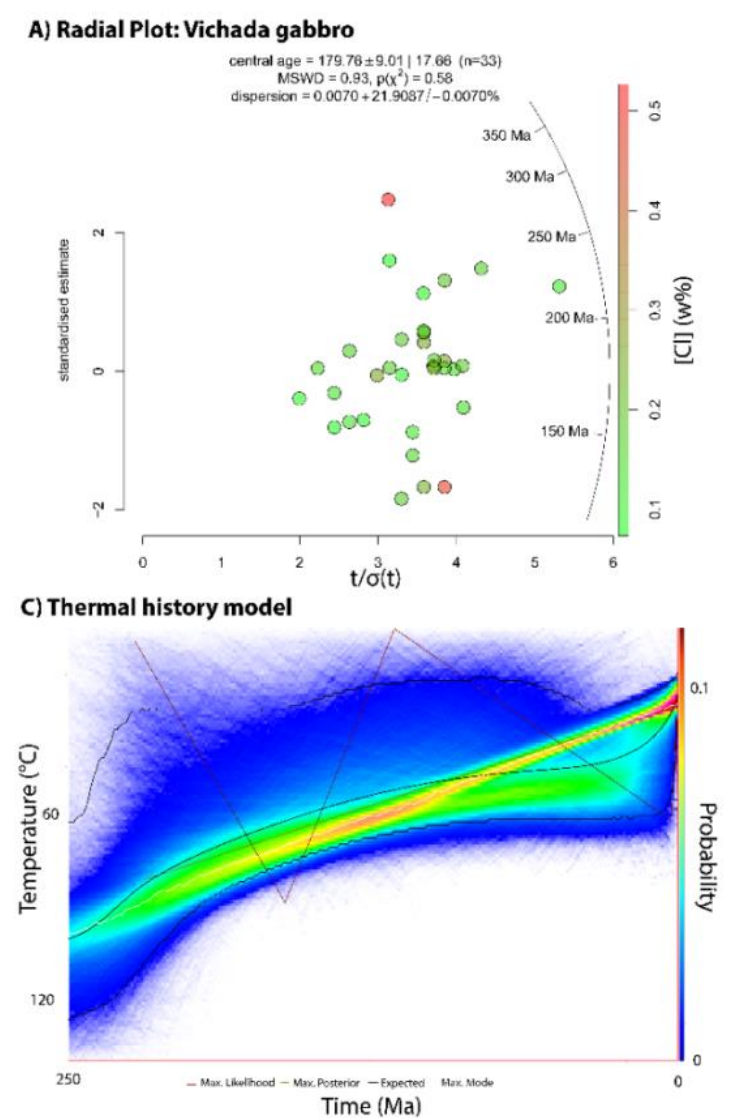

B) Fission track length $(\mu \mathrm{m})$ vs. angle with c-axis

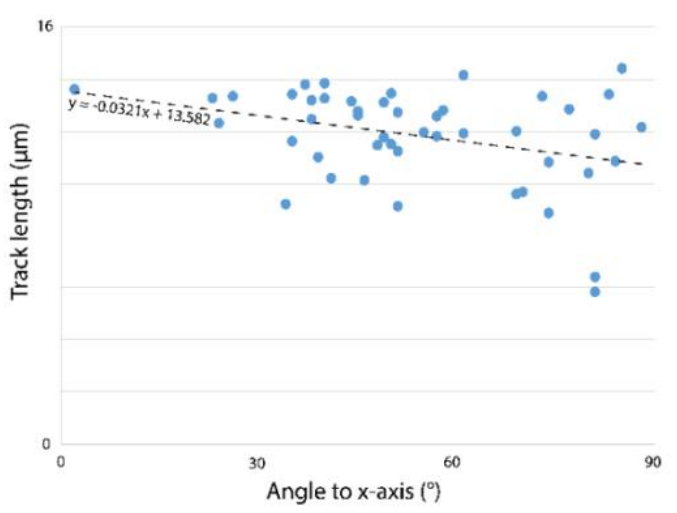

D) Expected Tt model fit (c-axis projected length data)

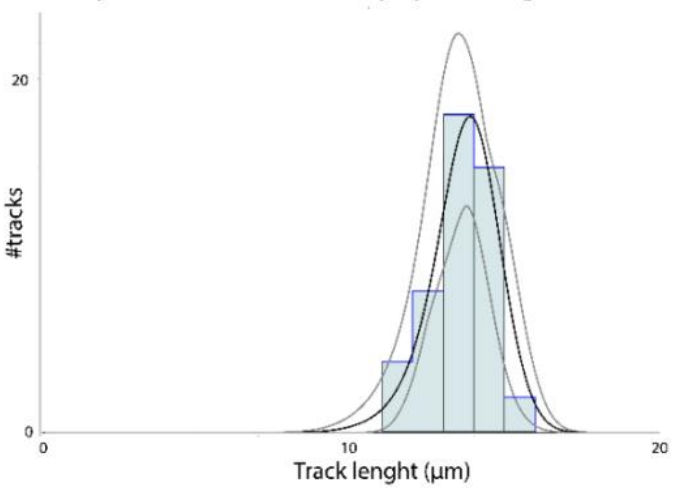

Figure 11 Apatite fission track results of the Vichada gabbro sample Af-7. (A) Radial plot of the analyzed sample with compositional data added as colour scale (using IsoPlotR; (Vermeesch, 2018)). (B) Scatter plot indicating the decreasing trend for apatite fission track length with angle to the c-axis. (C) Thermal history model performed with QTQt (Gallagher, 2012) illustrating the slow cooling through the apatite partial annealing zone $\left(\sim 60^{\circ}-120^{\circ} \mathrm{C}\right)$. (D) Model fit of the expected Tt model (i.e. the black curve in panel C) with the c-axis projected length data. 
539 As the "Caño Viejita" gabbro is limited to the north by a $\sim 50 \mathrm{~m}$ thick sedimentary sequence

540 (Figure 4A) which begins north of the intrusion in a creek valley, no clear contact was visible 541 nor a confident extension estimate can be made. Thus, simple field observations did not allow 542 concluding if the gabbro intruded the sediments or if on the contrary the sediments covered 543 the exhumed intrusion at a later stage. This issue will be discussed later in this section.

545 Lacking quartz and low $\mathrm{SiO}_{2}$ contents as well as the occurrence of fayalite, pyroxene and 546 bytownite-anorthite as main minerals, point to a mafic to ultramafic primary magma. These 547 observations are consistent with the $\mathrm{Al}_{2} \mathrm{O}_{3}$ contents from $15.55 \%$ to $15.83 \%$, and the low $\mathrm{Zr}$ 548 contents are in agreement with a continental alkaline metaluminous gabbro of Within-Plate 549 characteristics as confirmed by the geochemical-petrotectonic discrimination diagrams 550 (Error! Reference source not found.). However, alkali feldspar, mentioned as characteristic 551 of the latter two (Le Maitre et al., 2002), were not found in thin-section nor XRD.

553 The former seems somewhat in contradiction with the rather low $\mathrm{CaO}$ and $\mathrm{MgO}$ 554 concentrations and high $\mathrm{K}_{2} \mathrm{O}$ and $\mathrm{Na}_{2} \mathrm{O}$ content (Table 2). However, the latter can be 555 explained by the influence of continental crust reworking and/or magma mixing as part of an 556 aborted rifting process. The high $\mathrm{FeO}_{\text {tot }}(\sim 11 \%)$ and $\mathrm{TiO}_{2}$ content $(3.12 \%$ to $3.43 \%)$ is 557 expressed in abundant ilmenite and fayalite, and the high $\mathrm{P}_{2} \mathrm{O}_{5}(1.54-1.72 \%)$ evidenced in the 558 numerous large apatite crystals may reflect the initial formation of immiscible Ti-Fe-P melts, 559 that, due to their higher density, typically reflect the bottom of mafic intrusions. Interestingly, 560 titanian pyroxene was not found, showing that Ti was hugely scavenged before by ilmenite 561 and to a lesser extent rutile crystallization. The iron incorporation into ilmenite, pyroxene and 
562 olivine of very fayalitic composition is also in agreement with the low Mg content. Virtually no 563 magnetite was found in spite of some rutile needles. This all indicates a rather low $\mathrm{fO}_{2}$ and 564 low liquidus temperature in a highly evolved mafic magmatic system, although still far away 565 from peralkaline miaskitic or much less agpaitic rocks (Marks and Markl, 2017).

566 This work also confirms the utility of apatite trace elements analysis for petrogenetic or 567 exploration purposes (e.g. Mao et al.2016 and references herein). Although the LA-ICP-MS 568 data acquisition was not especially performed for apatite trace elements analysis, using for 569 example the discrimination patterns proposed by Belousova et al. (2002) some light is put on 570 the apatite and gabbro genesis, considering also the absence of observable concurrent 571 phosphate minerals (monazite or xenotime) or garnets which tend to scavenge most of 572 incompatible and RE elements.

573

574 The strong enrichment mainly of the LREE with a nearly log-linear decrease slope to heavier $575 \mathrm{REE}(\mathrm{Ce} / \mathrm{Yb})_{\mathrm{cn}}$ of $\left.\left.12-13\right)\right)$ and a moderate negative Eu-anomaly $(2 \mathrm{Eu} /(\mathrm{Sm}+\mathrm{Gd}))_{\mathrm{cn}}$ of $\left.0.62-0.7\right)$ 576 (Error! Reference source not found.) are common patterns observed in many apatites. The 577 negative Eu-anomaly was probably controlled by former or simultaneous plagioclase 578 crystallization (e.g. Rollinson, 1993) much more than the own apatite redox-state, and would 579 decrease with further magmatic differentiation as observed e.g. in granites. In contrast, mid580 ocean ridge gabbro apatites nearly don't show LREE enrichment in comparison with HREE 581 (see Mao et al. 2016). The dispersion in the apatites of LREE (e.g. La 261- 1030 ppm, Ce 582 770-2590ppm) exceeding for example the dispersion of HREE and $\mathrm{Y}$ (328-984ppm) is much 583 more pronounced than the nearly invariant trace elements $\mathrm{Sr}$ (516-747ppm) or Mn (358584 478ppm). Mn decreases slightly together with $\mathrm{Sr}$, whereas between $\mathrm{Y}$ and $\mathrm{Sr}$ a strong scatter 585 exists. However, the clear positive correlation between Th and Ce (Fig. 8B) as well as 
between $Y$ and the REE-sum, evidences their enrichment during the crystallization process.

587 Also both the Th/Ce and Y/REE contents and ratios indicate a more reducing environment

588 (Belousova et al., 2002), whereas for the redox sensitive Mn the picture is not so clear:

589 assuming higher $\mathrm{Sr}$ as indicator of less differentiated and more reduced magma, the coupled

590 decrease of $\mathrm{Sr}$ and $\mathrm{Mn}$ may be caused by the preferred incorporation of $\mathrm{Mn}_{2+}$ instead of $\mathrm{Mn}_{3+}$

591 or $\mathrm{Mn}_{4+}$ in apatite where it substitutes directly for $\mathrm{Ca}_{2+}$ in the two Ca-sites. This assumption is

592 also supported by the slightly positive Ce-anomaly with the preferential incorporation of $\mathrm{Ce}_{3+}$ 593 on the ${ }_{[9]} \mathrm{Ca} 1-$ site and the corresponding valence balancing through, e.g. $\mathrm{Na}+$.

595 The comparison with the discrimination diagrams of Belousova et al. (2002) give the following 596 picture: The $\mathrm{Sr} / \mathrm{Y}$ values (Sr 516-747ppm / Y 328-934ppm) occupy the fields of granitoid but 597 more the mafic rocks to Fe-ore fields. $(\mathrm{Ce} / \mathrm{Yb})_{\text {cn }}$ of $12-13$ and Sum REE $0.2-0.6$ wt. \% are in 598 the granitoid and near the dolerite field. Sr 516-747ppm/ Mn 358-478ppm correlations are in 599 the larvikites, jacupirangite and iron ore fields, $\mathrm{Y} 328-934 \mathrm{ppm} / \mathrm{Eu} / \mathrm{Eu}^{*} 62-0.7$ occupy the 600 granitoids, mafic rocks and iron ore fields. The high $\mathrm{P}$ concentrations in the Fe-ore fields like 601 Durango or Kiruna, but also in some of the Fe-Ti-P deposits worldwide as well as the 602 enrichment of $\mathrm{K}$ are in agreement with the overlapping of most of these mafic to granitoide 603 and immiscibility magma fields.

604 Neither etching nor the CL images reveal zonation or growth patterns in the apatites. Zircons 605 seem to have crystalized first and were then enclosed by ilmenites or later between nearly 606 coeval plagioclase and pyroxene grains, where also early formed rutile needles are frequent. 607 Altogether, petrologic evidence and main elements as the high $\mathrm{K}, \mathrm{P}$, and $\mathrm{Na}$ content of the 608 gabbro as well as the apatite trace element geochemistry (high Ce/Yb etc.) plaid against an 609 ophiolite subduction-related origin of the Vichada Viejita Creek gabbro, favoring instead an 
610 aborted continental rifting process with relatively low fo2, little water (no amphiboles nor mafic

611 pegmatites) and low $\mathrm{Cl}$ content. As fluxing agent, phosphorous may have played an important

612 role in the system. Some of the gabbro whole-rock and apatite geochemical characteristics

613 hint to sediment or continental crust recycling, but also to magma mixing with some 614 lamprophyre, carbonatite or anorthosite associated Fe-Ti-P signatures.

615

616 The two U-Pb principal ages obtained from 25 (Af-1) and 35 (Af-7) apatite grains, 617 respectively, are discordant and show a scattering of individual grain ages. They yield lower 618 intercept ages of $1001 \pm 59 \mathrm{Ma}(\mathrm{Af}-1)$ and $961 \pm 61 \mathrm{Ma}(\mathrm{Af}-7)$ with a $207 \mathrm{~Pb} / 206 \mathrm{~Pb}$ initial value 619 of 0.945 (Figure 10). Adjusting them to the Pb evolution model of Stacey and Kramers (1975), 620 we obtain similar ages of $975 \pm 9 \mathrm{Ma}(\mathrm{Af}-1)$ and $1002 \pm 21 \mathrm{Ma}$ (Af-7), with Af-1 showing no 621 lower scattering. This rather broad range in ages may have two principal reasons: either 622 analytical-procedural based dispersion, or geological-mineralogical factors and their 623 interaction. The low scatter of analytical data of the different standard apatites used during 624 measurement suggest a rather stable instrument configuration and no measuring 625 disturbance. However, apart from differences between the two sample groups from different 626 parts of the gabbro also the different analytic procedures have contributed, as in the second 627 case also AFT data were to be obtained. Among the geological-mineralogical factors, first the 628 rather high proportion of common (non-radiogenic) $\mathrm{Pb}$ is to be mentioned, inhomogeneities of 629 HFSE incorporation during the crystallization process as also evidenced by the high REE 630 scattering in the apatite samples from gabbro Af-7; the homogeneous CL-images of apatites 631 from Af-1 suggest no zonation during apatite growth. Although the U-Pb apatite closure 632 temperature of $\sim 500^{\circ} \mathrm{C}$ is much lower than for zircons (Chew and Spikings, 2015) and than 633 the magma emplacement temperature $\left(>1000{ }^{\circ} \mathrm{C}\right.$ or perhaps lower due to continental 634 contaminants, fluids and high P) neither diffusion effects during the cooling process nor later 
635 thermal peaks can be ruled out. So there is no doubt that both apatite U-Pb ages show a 636 common history related to the magmatic emplacement and cooling process and much more 637 unlikely posterior thermal events. Small mafic bodies as the Viejita Creek gabbro tend to 638 solidify and cool below the apatite closure temperature in less than $\sim 100$ years. Additionally, 639 the absence of metamorphic overprinting signs both in rocks and thin-sections, rule out 640 stronger posterior thermal events.

641 This Early Neoproterozoic Viejita Creek gabbro exhibit strong similarities with other mafic 642 bodies outcropping hundreds of kilometers to the south near to the Vaupés and Apaporis 643 rivers extending at least until Brazil (Figure 2). Their radiometric ages are considerably older 644 (100-200 Ma), however, but also were obtained by other radiometric methods $(\mathrm{K} / \mathrm{Ar}+\mathrm{Rb} / \mathrm{Sr})$. 645 The $\mathrm{Rb} / \mathrm{Sr}$ isochrons are considered to give too low regional ages with very large error 646 margins (Kroonenberg et al., 2016). Such a large time difference only caused because of 647 analytical differences is not very probable, but we don't have enough elements for a definite 648 conclusion, at the moment.

650 The reported time window of Neoproterozoic mafic magmatism in the western Amazonian 651 craton span from 940 to $1225 \mathrm{Ma}$ (Table 1). To the East (Brazilian Taraira) are some of the 652 youngest reported ages $\sim 940$ to $980 \mathrm{Ma}$ (Tassinari, 1996), and moreover there seems to be 653 a South-to-North trend from older to younger magmatism, possibly indicating several cycles 654 of cortical opening and closing in different parts of the craton. About $200 \mathrm{~km}$ to the East of our 655 study area, the youngest known intracratonic magmatic rocks in the NW Amazonian Craton, 656 the Nepheline Syenite of San José del Guaviare, of Neoproterozoic-Ediacaran to Cambrian 657 ages of $\sim 578 \mathrm{Ma}$ (Mejia et al., 2012) and biotite K/Ar and Rb/Sr cooling ages of $445-495 \mathrm{Ma}$ 658 (Pinson et al., 1962) outcrops over > 10 square kilometers. Recently obtained own LA-ICP- 
MS U-Pb zircon ages of $\sim 609 \mathrm{Ma}$ in the southern extension near Jordan (Franco et al., 2018; Muñoz Rocha et al., 2019) suggest a long emplacement and cooling history for this large body. Further west, no intracratonic intrusions are reported until now. Anyhow, the San José del Guaviare Nepheline Syenite is another indication of tectonic reactivation of structural weakness zones in the crust, possibly representing older suture or rift zones. Whilst in the case of the older Viejita Creek gabbro the Grenvillian orogeny as partial response to the Rodinia Supercontinent assembly some $1 \mathrm{Ga}$ ago was the most likely cause producing a distinctive enrichment of $\mathrm{Ti}, \mathrm{K}, \mathrm{P}$ and REEs in apatites from the mantel-derived magma, the magmatic differentiation of the Nepheline Syenite, coeval but not necessarily caused by the Pan-African-Braziliano orogeny, produced more agpaitic rocks and characteristic minerals such as large zircon crystals.

Also other alkaline to carbonatitic intrusions in the NW Amazonian Craton may be related to Grenvillian sequences s.I. (Cordani et al., 2010) or later events. The Nepheline Syenites of the Muri Alkaline Complex are dated between $1026 \pm 28$ Ma (Issler et al., 1975) and 1090 Ma (Kroonenberg et al., 2016). For the Nb-rich Seis Lagos Carbonatite Complex (SLCC) in Brazil near to the Colombian border, Rossoni et al. (2017) established an U-Pb zircon maximum age of $1328 \mathrm{Ma}$, at the very beginning of the Grenvillian, but other authors attribute much younger ages, which span from the Cambrian to the Triassic (Pinheiro et al., 1976). For the diamondiferous Guaniamo layered kimberlite sheets in Venezuela, ages between 840 and $710 \mathrm{Ma}$ are claimed (Channer et al., 2001).

These examples illustrate sufficiently, how much work is still to be done in the often difficult to access and covered areas of the Amazonian Craton in order to get an indisputable and generally accepted reconstruction of the Craton's history. Much better defined in this sense 
are the anorogenic granites such as the Parguaza Rapakivi Batholith from $1392 \pm 5$ Ma to $1402 \pm 2$ Ma in Colombia (Bonilla et al., 2013), although this is younger than the ages of the batholith reported in Venezuela of $\sim 1545 \mathrm{Ma}$. The comparable felsic Matraca rapakivi granites (Bonilla et al., 2016) seem to have a narrow correlation with U-Pb LA-ICP-MS ages of 1381 - $1343 \mathrm{Ma}$ from pegmatitic monazite and xenotime of the Chorrobocon colluviums in the Colombian Guainía Department (Franco et al., 2019), where granitic intrusions and associated mineralizations prove to be much more prominent than in other portions of the Mitú Complex (Bonilla et al., 2019).

With respect to the relation between the intrusive and the sandstone cover mentioned in the beginning of this chapter, another gabbro outcrop $\sim 10 \mathrm{~km}$ to the west of the study area (Cerro Siare, Figure 3) may give some hints. This gabbro consists of $55-60 \%$ plagioclase, $3-5 \%$ pyroxene, $2-8 \%$ olivine and $25-30 \%$ chlorite and crosscuts as a vertical dike the sandstone sequence, as reported by Franco (2002). Initially, Vesga \& Castillo (1972) described the sedimentary sequence informally as "Raudales-Iteviare Sandstone". However, in the updated Colombian Geological Map (Gómez Tapias et al., 2015) these sediments are now correlated with the Ordovician Araracuara Formation (without reported ages). But the detailed description of this unit by Franco (2002), who recognized a detailed column of 372 m thick sub-arkoses to quartz sandstones and conglomeratic sandstones as part of the Mapiripana Formation of Mesoproterozoic age is very convincing, although much more study including field work and geochronology has to be done for a final conclusion. The Mapiripana Formation as well as the La Pedrera Formation are more likely part of a northern extension of the Tunui Group (Pinheiro et al., 1976), which also forms the gold-rich Naquén and Caranacoa mountains of Mesoproterozoic age. All of them seem to represent molasse deposits of different oogenesis eroded long after the consolidation of the Roraima Formation. 
709 In the latter, detrital zircon U-Pb ages of 2171-1958 Ma (Santos et al., 2003) indicate a Trans710 Amazonian Orogeny origin of the sediments (Kroonenberg et al., 2016), with more or less 711 well developed metamorphic overprinting. The series of Neoproterozoic gabbros could have 712 intruded and cut rocks of the Mitu Complex (Bonilla et al., 2019; Galvis et al., 1979; López et 713 al., 2007; Rodríguez et al., 2011) as part of the 1.80-1.55 Ga Rio Negro-Juruena 714 Geochronological Province (Figure 2) in Colombia (Tassinari, 1996; Tassinari and 715 Macambira, 1999) and also the 1.87-1.5 Ga Roraima-Formation-like sedimentary covers 716 (Tunui Group). The oldest metamorphic overprint of those sediments was dated at $\sim 1.3 \mathrm{Ga}$ 717 and related with the incipient Grenvillian event (Kroonenberg and de Roever, 2010). 
719 The Amazonian Craton as a whole seems to have behaved as a rigid block where 720 deformation mostly concentrated along pre-existing major shear zones that could accompany 721 the uplift of the intervening blocks, the development of rift basins, emplacement of bi-modal 722 magmatic suites and extensional fractures which were filled by mafic dike swarms (Cordani et 723 al., 2010) or intrusions. This suggests that granitic, mafic and syn-sedimentary sequences of 724 Grenvillian age outcropping in the Colombian Rio Negro Juruena Province would be the 725 result of different stages of intraplate rifting and shearing induced by continent-continent 726 collision (Putumayo Orogen and Sunsás belt). This tectonic regime hence also created easier 727 pathways for the ascent of magmas. The Viejita Creek Gabbro represents such a mafic body 728 associated with intraplate rifting, as a response to the Rodinia Supercontinent assembly. This mafic intrusion contains a rare lithology in this part of the Amazonian Craton where felsic rocks of the Rio Negro-Juruena province predominate. This points to a mantle origin with high

731 crustal influence or magma mixing and rifting caused by significant collisions like those 732 assumed to have occurred during the Grenvillian.

The NE-SW and NW-SE structural trends in the Eastern Colombian basement are visible as 735 main lineaments all over the Amazonian Craton. They were interpreted mainly as the result of 736 compression during Mesoproterozoic accretion stages (Galvis et al., 1979; Tassinari and 737 Macambira, 1999) such as the Rondonian-San Ignacio orogeny, or the Sunsás orogeny 738 (Cordani et al., 2010). In this context, our data and other research suggest that the mafic 739 intrusion occurred related with a NW-SE trending intra plate or rifting event some 970 Ma ago 740 (or slightly before) affecting the Rio Negro Juruena Province. This may have been associated 741 with the Putumayo Orogeny (Ibañez et al., 2015) proposed for the late phases of the 
Amazonia-Baltica-Laurentia collision. Possibly in this context or earlier, a sedimentary basin opened, accommodating the deposition of sediments during the late Mesoproterozoic.

In relation to the gabbro's exhumation process, the apatite fission track central age of $179.8 \pm$ 9.0 Ma extracted from 47 measurements of high-quality apatite crystals (Figure 11), allow some preliminary conclusions for developing a thermal history model. The time-temperature path with the highest probability suggests continuous and slow cooling through the Apatite Partial Annealing zone during the Meso- and Cenozoic, since the Jurassic.

The understanding of the thermal history of the Colombian part of the Amazonian craton is in its beginning and requires more thermochronological data. Apatite and zircon fission track thermochronology until now focused mainly on the Andes Cordillera, where mostly Andean, i.e. Cenozoic ages are retrieved from basement rocks (Amaya et al., 2017; Parra et al., 2009; Villagómez and Spikings, 2013). The analyzed samples exhumated $\sim 400 \mathrm{~km}$ southeastwards of the Andean thrust front or Borde Llanero Fault System (Restrepo-Pace and Cediel, 2010), did not cool rapidly as would result from an Andean orogeny uplift, but rather experienced a gradual, slow cooling through the $120^{\circ}-60^{\circ} \mathrm{C}$ temperature window (Apatite Partial Annealing Zone). This slow cooling occurred in the regional context of Mesozoic extension during which backarc and marginal basins developed in western South America (Coney and Evenchick, 1994; Dalziel, 1986; Mpodozis and Ramos, 1989). The source-material for these basins were predominantly clastic sediments originating from the cratonic lithosphere (e.g. Horton, 2018 and references therein). Further possible geochronological evidence for the gradual slow erosion of the Grenvillian remnants are found in the Llanos basin to the west of our study area, in which the 950-1050 Ma age population is one of the most dominant zircon U-Pb age 
766 767 2010).

768

populations of the sedimentary record from the Paleozoic to the Late Cenozoic (Horton et al.,

\section{Acknowledgements}

The first author wishes to acknowledge the PhD-studies grant received by COLCIENCIAS. SN got funds through a PhD fellowship from the Research Foundation Flanders (FWO). Sampling and analysis were also possible due to Zeze Amaya, Ana Elena Concha and others. Two anonymous reviewers helped to improve the manuscript on important aspects

\section{Bibliography}

Almeida, M.E., Larizzatti, J.H., 1996. Geologia e petrografia da Suíte Intrusiva Içana no alto rio Uaupés, Estado do Amazonas, Brasil., in: SBG, Congresso Brasileiro de Geologia, 39. Balneário de Camboriú, pp. 399-403.

Almeida, M.E., Luzardo, R., S.S., P., Oliveira, M.A., 2004. Folha NA.19-Pico da Neblina. In: Schobbenhaus, C., Gonçalves, J.H., Santos, J.O.S., Abram, M.B., Leão Neto, R., Matos, G.M.M., Vidotti, R.M., Ramos, M.A.B., Jesus, J.D.A. de. (eds.). Carta Geológica do Brasil ao Milionésimo. Brasília.

Almeida, M.E., Macambira, M.J.B., Scheller, T., 1997. Içana Intrusive Suite: age $207 \mathrm{~Pb} / 206 \mathrm{~Pb}$ (zircon evaporation) of muscovite bearing granite, Amazonas State, Brazil, in: South American Symposium on Isotope Geology, 1. Campos do Jordao, pp. 31-33.

Anders, E., Grevesse, N., 1989. Abundances of the elements: Meteoric and solar. Geochimica et Cosmochimica Acta 53, 197-214.

Amaya, S., Zuluaga, C.A., Bernet, M., 2017. New fission-track age constraints on the exhumation of the central Santander Massif: Implications for the tectonic evolution of the 


$$
\text { Northern Andes, Colombia. Lithos }
$$

282-283,

388-402. https://doi.org/https://doi.org/10.1016/j.lithos.2017.03.019

Belousova, E.A., Griffin, W.L., O’Reilly, S.Y., Fisher, N.I., 2002. Apatite as an indicator mineral for mineral exploration: trace-element compositions and their relationship to host rock type. Journal of Geochemical Exploration 76, 45-69. https://doi.org/10.1016/S0375$6742(02) 00204-2$

Bettencourt, J.S., Tosdal, R.M., Leite Jr., W.B., Payolla, B.L., 1999. Mesoproterozoic rapakivi granites of the Rondonia Tin Province, southwestern border of the Amazonian craton, Brazil-I. Reconnaissance U-Pb geochronology and regional implications. Precambrian Res. 95, 41-67. https://doi.org/10.1016/S0301-9268(98)00126-0

Bonilla, A., Frantz, J.C., Charão-Marques, J., Cramer, T., Franco, J.A., Mulocher, E., AmayaPerea, Z., 2013. Petrografía, Geoquímica y Geocronología del Granito de Parguaza en Colombia. Bol. Geol. 35, 83-104.

Bonilla, A., Frantz, J.C., Charão-Marques, J., Cramer, T., Franco, J.A., Amaya-Perea, Z., 2016. Magmatismo rapakivi en la cuenca media del río Inírida, departamento de Guainía, Colombia. Bol. Geol. 38 , 17-32. https://doi.org/http://dx.doi.org/10.18273/revbol.v38n1-2016001

Bonilla, A., Cramer, T., Poujol, M., Cano, H., Franco, J.A., Amaya, Z., 2019. Petrografía, geoquímica y geocronología $U$ / Pb en circones de rocas ígneas y metamórficas a lo largo del Río Cuiarí en el sur del Departamento de Guainía, Colombia. Bol. Geol. 41, 55-84. https://doi.org/10.18273/revbol.v41n1-2019003

Cardona, A., Chew, D., Valencia, V.A., Bayona, G., Mišković, A., Ibañez, M., 2010. Grenvillian remnants in the Northern Andes: Rodinian and Phanerozoic paleogeographic perspectives. J. South Am. Earth Sci. 29, 92-104. https://doi.org/10.1016/j.jsames.2009.07.011 
Cardona, A., Valencia V, A., Bayona, G., Duque, J., Ducea, M., Gehrels, G., Jaramillo, C., Montes, C., Ojeda, G., J., R., 2011. Early-subduction-related orogeny in the northern Andes: Turonian to Eocene magmatic and provenance record in the Santa Marta Massif and Rancheria Basin, northern Colombia. Terra Nov. 23, 26-34. https://doi.org/doi:10.1111/j.1365-3121.2010.00979.x

Carneiro, M.C.R., Nascimento, R.S.C., Almeida, M., Trindade, I.R., Salazar, C.A., 2017a. Leucognaisses alcalinos no Dominio Imeri, Provincia Rio Negro-NW do Estado do Amazonas. https://doi.org/10.13140/RG.2.2.19376.35840

Carneiro, M.C.R., Nascimento, R.S.C., Almeida, M.E., Salazar, C.A., Trindade, I.R. da, Rodrigues, V. de O., Passos, M.S., 2017b. The Cauaburi magmatic arc: Lithostratigraphic review and evolution of the Imeri Domain, Rio Negro Province, Amazonian $\begin{array}{lllll}\text { Craton. J. South } & \text { Am. }\end{array}$ https://doi.org/10.1016/j.jsames.2017.06.001

Channer, D.M.D., Egorov, A., Kaminsky, F., 2001. Geology and structure of the Guaniamo diamondiferous kimberlite sheets, south-west Venezuela. Rev. Bras. Geociências 31, 615-630. https://doi.org/10.25249/0375-7536.2001314615630

Chew, D.M., Babechuk, M.G., Cogné, N., Mark, C., O’Sullivan, G.J., Henrichs, I.A., Doepke, D., McKenna, C.A., 2016. (LA,Q)-ICPMS trace-element analyses of Durango and McClure Mountain apatite and implications for making natural LA-ICPMS mineral $\begin{array}{llll}\text { standards. } & \text { Chem. } & \text { Geol. }\end{array}$ https://doi.org/https://doi.org/10.1016/j.chemgeo.2016.03.028

Chew, D.M., Spikings, R.A., 2015. Geochronology and Thermochronology Using Apatite: Time and Temperature, Lower Crust to Surface. Elements 3, 189-194.

Cochrane, R., Spikings, R.A., Chew, D., Wotzlaw, J.F., Chiaradia, M., Tyrrell, S., Schaltegger, U., Van der Lelij, R., 2014. High temperature $\left(>350^{\circ} \mathrm{C}\right)$ thermochronology and 
mechanisms of $\mathrm{Pb}$ loss in apatite. Geochim. Cosmochim. Acta 127, 39-56. https://doi.org/10.1016/j.gca.2013.11.028

Cogné, N., Chew, D. M., Donelick, R. A. Ansberque, C., 2019. LA-ICP-MS apatite fission track dating: A practical zeta-based approach,Chemical Geology, In Press.https://doi.org/10.1016/j.chemgeo.2019.119302

Coney, P.J., Evenchick, C.A., 1994. Consolidation of the American Cordilleras. J. South Am. Earth Sci. 7, 241-262. https://doi.org/https://doi.org/10.1016/0895-9811(94)90011-6

Cordani, U.G., Fraga, L.M., Reis, N., Tassinari, C.G., Brito-Neves, B.B., 2010. On the origin and tectonic significance of the intra-plate events of Grenvillian-type age in South America: A discussion. J. South Am. Earth Sci. 29, 143-159. https://doi.org/10.1016/j.jsames.2009.07.002

Cordani, U.G., Sato, K., Sproessner, W., Fernandes, F.S., 2016. U-Pb zircon ages of rocks from the Amazonas Territory of Colombia and their bearing on the tectonic history of the NW sector of the Amazonian Craton, Brazilian Journal of Geology. https://doi.org/10.1590/2317-4889201620150012

Cordani, U.G., Tassinari, C.C.G., Teixeira, W., Basei, M.A.S., Kawashita, K., 1979. Evolução tectônica da Amazônia com base nos dados geocronológicos. Actas. PP - Ciudad Arica.

Cordani, U.G., Teixeira, W., D’Agrella-Filho, M.S., Trindade, R.I., 2009. The position of the Amazonian Craton in supercontinents. Gondwana Res. 15, 396-407. https://doi.org/10.1016/j.gr.2008.12.005

Cox, K.G., Bell, J.D., Pankhurst, R.J., 1979. The interpretation of igneous rocks, George All. ed. London.

Dall'Agnol, R., Costi, H.T., Leite, A.A. da S., de Magalhães, M.S., Teixeira, N.P., 1999. Rapakivi granites from Brazil and adjacent areas. Precambrian Res. 95, 9-39. https://doi.org/10.1016/S0301-9268(98)00125-9 
Dalziel, I.W.D., 1986. Collision and Cordilleran orogenesis: an Andean perspective. Geol. Soc. London, Spec. Publ. 19, 389-404. https://doi.org/10.1144/GSL.SP.1986.019.01.22

Departamento Nacional da Producäo Mineral, 1976. Folha NA. 19 Pico da Neblina: geología, geomorfología, pedología, vegetaeäo e uso potencial da terra. Proj. Radambras. Levant. Recur. Nat. 11, 380.

Dewanckele, J., De Kock, T., Fronteau, G., Derluyn, H., Vontobel, P., Dierick, M., Van Hoorebeke, L., Jacobs, P., Cnudde, V., 2014. Neutron radiography and X-ray computed tomography for quantifying weathering and water uptake processes inside porous limestone used as building material. Mater. Charact. 88, 86-99. https://doi.org/10.1016/j.matchar.2013.12.007

Donelick, R.A., Ketcham, R.A., Carlson, W.D., 1999. Variability of apatite fission-track annealing kinetics: II. Crystallographic orientation effects. Am. Mineral. 84, 1224-1234. https://doi.org/10.2138/am-1999-0902

Donelick, R.A., O’Sullivan, P.B., Ketcham, R.A., 2005. Apatite fission-track analysis, Low Temperature Thermochronology: Techniques, Interpretations, and Applications. Reviews in Mineralogy and Geochemistry.

Franco, D., 2002. Estratigrafía, petrografía y análisis de proveniencia de la secuencia sedimentaria aflorante en la Serranía de Mapiripana, departamentos de Guainía y Vichada. Thesis. Universidad Nacional de Colombia.

Franco, J.A., Muñoz, J.A., Piraquive, A., Bonilla, A., Cramer, T., Campos, H., 2018. Geochronology of the Nepheline Syenite of el Jordán, Guaviare Colombia, evidences of Neoproterozoic- Cambrian intraplate magmatism and its implications during Pan- African tectonics in western Gondwana., in: Geophysical Research Abstracts Vol. 20, EGU201810861, 2018 EGU General Assembly 2018. Vienna, p. 10861.

Franco, J.A., Cramer, T., Bonilla, A., 2019. Critical minerals in Colombia, characteristics, ages 
and potential of Ti-Nb-Ta, REE and U-Th mineralizations in Cerro Espina, Guainía. In progress.

893

894

895

896

897

898

899

900

901

902

903

904

905

906

907

908

909

910

911

912

913

914

915

Gallagher, K., 2012. Transdimensional inverse thermal history modeling for quantitative thermochronology. J. Geophys. Res. Solid Earth 117. https://doi.org/10.1029/2011JB008825

Galvis, J., Huguett, A., Ruge, P., 1979. Geología de la Amazonía Colombiana. Bol. Geológico.

Gansser, A., 1954. The Guiana Shield (S. America) Geological Observations. Eclog. Geol. Helvet 47, 77-112.

Gaudette, H.E., Mendoza, V.S., Hurley, P.M., Fairbairn, H.W., 1978. Geology and age of the Parguaza rapakivi granite, Venezuela. Bull. Geol. Soc. Am. 89, 1335-1340. https://doi.org/10.1130/0016-7606(1978)89<1335:GAAOTP>2.0.CO;2

Gómez Tapias, J., Montes Ramírez, N.E., Nivia Guevara, Á., Diederix, H. (Eds.), 2015. Atlas Geológico de Colombia, Plancha 5-15AGC 2015. Scale 1:500 000. Servicio Geológico Colombiano, Bogotá.

Harlov, D.E., 2015. Apatite: A Fingerprint for Metasomatic Processes. Elements 11, 171-176. https://doi.org/10.2113/gselements.11.3.171

Hasebe, N., Barbarand, J., Jarvis, K., Carter, A., Hurford, A., 2004. Apatite fission-track chronometry using laser ablation ICP-MS. Chem. Geol. 207, 135-145. https://doi.org/10.1016/j.chemgeo.2004.01.007

Hoffman, P.F., 1991. Did the Breakout of Laurentia Turn Gondwanaland Inside-Out? Science (80-. ). 252, 1409-1412. https://doi.org/10.1126/science.252.5011.1409

Horton, B. K., 2018. Tectonic Regimes of the Central and Southern Andes: Responses to Variations in Plate Coupling During Subduction. Tectonics 37, 402-429. https://doi.org/doi:10.1002/2017TC004624 
Horton, B.K., Parra, M., Saylor, J.E., Nie, J., Mora, A., Torres, V., Stockli, D.F., Strecker, M.R., 2010. Resolving uplift of the northern Andes using detrital zircon age signatures. GSA Today 20, 4-9. https://doi.org/10.1130/GSATG76A.1

Huguett, A., 1977. Geología de la Comisaría del Guainía, Colombia, en base a imágenes de radar, Carta Técnica. Ministerio de Minas y Energía, Instituto Nacional de Investigaciones Geologico-Mineras,Proyecto Radargramétrico del Amazonas, Bogotá.

Hurford, A.., Green, P.., 1983. The zeta age calibration of fission-track dating. Chem. Geol. 1, 285-317.

Ibañez, M., 2010. New U-Pb geochronological insights into the Proterozoic tectonic evolution of Northwestern South America: The Mesoneoproterozoic Putumayo Orogen of Amazonia and implications for Rodinia Reconstructions. The University of Arizona.

Ibáñez-Mejía M, Ruiz J, Valencia VA, Cardona A, Gehrels GE, Mora AR., 2011. The Putumayo Orogen of Amazonia and its implications for Rodinia reconstructions: new U$\mathrm{Pb}$ geochronological insights into the Proterozoic tectonic evolution of northwestern South America. Precambrian Res 191:58-77

Ibañez, M, Pullen, A., Arenstein, J., Gehrels, G.E., Valley, J., Ducea, M.N., Mora, A.R., Pecha, M., Ruiz, J., 2015. Unraveling crustal growth and reworking processes in complex zircons from orogenic lower-crust: The Proterozoic Putumayo Orogen of $\begin{array}{llll}\text { Amazonia. } & \text { Precambrian } & \text { 285-310. }\end{array}$ https://doi.org/10.1016/j.precamres.2015.06.014

Issler, R.., de Lima, R.M.., Montalvao, G.., 1975. Magmatismo alcalino no craton Guianes, in: Anais Decima Conferencia Geologica Interguianas, Belem Do Para, Brazi. pp. 103-122. Janousek, V., Farrow, C.M., Erban, V., 2008. Geochemical Data Toolkit in R, version for Windows.

Ketcham, R., Carter, A., Donelick, R., Barbarand, J., Hurford, A.J., 2007. Improved modeling 
of fission-track annealing in apatite. Am. Mineral. 92, 799-810. https://doi.org/10.2138/am.2007.2281

Ketcham, R.A., Donelick, R.A., Carlson, W.D., 1999. Variability of apatite fission-track annealing kinetics: III. Extrapolation to geological time scales. Am. Mineral. 84, 12351255. https://doi.org/10.2138/am-1999-0903

Klemme, S., John, T., Wessels, M., Kusebauch, C., Berndt, J., Rohrbach, A., SchmidBeurmann, P., 2013. Synthesis of trace element bearing single crystals of Chlor-Apatite (Ca5(PO4)3Cl) using the flux growth method. Chem. Cent. J. 7, 56. https://doi.org/10.1186/1752-153X-7-56

Kroonenberg, S. B., 2019. The Proterozoic Basement of the Western Guiana Shield and the Northern Andes. In F. Cediel and R. P. Shaw (Eds.), Geology and Tectonics of Northwestern South America (pp. 115-192). Cham: Springer International Publishing. https://doi.org/10.1007/978-3-319-76132-9_3

Kroonenberg, S.B., de Roever, E.W.F., Fraga, L.M., Reis, N.J., Faraco, T., Lafon, J.-M., Cordani, U., Wong, T.E., 2016. Paleoproterozoic evolution of the Guiana Shield in Suriname: A revised model. Netherlands J. Geosci. 95, 491-522. https://doi.org/10.1017/njg.2016.10

Kroonenberg, S.B., de Roever, E.W.F., 2010. Geological Evolution of the Amazonian Craton, in: Hoorn, C., Wesseling, F.. (Eds.), Amazonia, Landscape and Species Evolution: A Look into the Past. Wiley-Blackwell Publishing Ltd., Oxford, UK, pp. 9-28. https://doi.org/10.1002/9781444306408.ch2

Mao, M., Rukhlov, A.S., Rowins, S.M., Spence, J., Coogan, L.A., 2016. Apatite Trace Element Compositions: A Robust New Tool for Mineral Exploration. Economic Geology 111, 1187-1222. https://doi.org/10.2113/econgeo.111.5.1187

Le Maitre, R., 1976. The Chemical Variability of some Common Igneous Rocks. J. Petrol. 17, 
Le Maitre, R., Streckeisen, A., Zanettin, B., Bas, M.J. Le, Bonin, B., Bateman, P., 2002.

Igneous Rocks: A Classification and Glossary of Terms: Recommendations of the International Union of Geological Sciences Subcommission on the Systematics of Igneous Rocks. Cambridge University Press, Cambridge.

López, J., Khurama, S., Bernal, L., Cuellar, M., 2007. EL Complejo Mitú: Una Nueva Perspectiva. Memorias XI Congr. Colomb. Geol. 1-16.

Marks, M.A.W., Markl, G., 2017. A global review on agpaitic rocks. Earth-Science Rev. 173, 229-258. https://doi.org/10.1016/j.earscirev.2017.06.002

McDonough, W.., Sun, S., 1995. The composition of the Earth. Chem. Geol. 120, 223-253. https://doi.org/10.1016/0009-2541(94)00140-4

McDowell, F.W., Mclntosh, W.C., Farley, K.A., 2005. A precise 40Ar-39Ar reference age for the Durango apatite (U-Th)/He and fission-track dating standard. Chem. Geol. 214, 249-263. https://doi.org/https://doi.org/10.1016/j.chemgeo.2004.10.002

Mejia, M.I.A., Garcia, G.Z., Martens, U., 2012. Caracterización petrográfica, geoquímica y edad de la sienita nefelínica de san josé del guaviare. Bol. Geol. 34, 15-26.

Mielke, J.E., 1979. Composition of the Earth's Crust and Distribution of the Elements, in: Siegel, F. ed., Review of Research on Modern Problems in Geochemistry - Earth Science Series 16: Paris, International Association for Geochemistry and Cosmochemistry, p. 13-37.

Mpodozis, C., Ramos, V., 1989. The Andes of Chile and Argentina, in: Geology of the Andes and its Relation to Hydrocarbon and Mineral Resources. Earth Sci. Ser. 11, 59-90.

Muñoz Rocha, J.A., Piraquive, A., Franco Victoria, J.A., Bonilla, A., Peña Urueña, L.M., Cramer, T., Rayo Rocha, L. del P., Villamizar Escalante, N., 2019. Megacircones ediacáricos de la sienita nefelínica de San José del Guaviare y su potencial como 
material de referencia para datación U/Pb mediante LA-ICP-MS. Boletín Geológico 45, 5-22. https://doi.org/10.32685/0120-1425/boletingeo.45.2019.484

993

Nockolds, S.R., 1954. Average chemical compositions of some igneous rocks. Bulletin of the Geological Society of America 65, 1007-1032.

Paquette, J., Piro, J., Devidal, J., Bosse, V., Didier, A., Sanac, S., Abdelnour, Y., 2014. Sensitivity enhancement in LA-ICP-MS by N2 addition to carrier gas: Application to radiometric dating of U-Th-bearing minerals. Agil. ICP-MS J. 58, 1-5.

Parra, M., Mora, A., Sobel, E.R., Strecker, M.R., González, R., 2009. Episodic orogenic front migration in the northern Andes: Constraints from low-temperature thermochronology in the Eastern Cordillera, Colombia. Tectonics 28. https://doi.org/10.1029/2008TC002423

Paton, C., Woodhead, J.D., Hellstrom, J.C., Hergt, J.M., Greig, A., Maas, R., 2011. Improved laser ablation $\mathrm{U}-\mathrm{Pb}$ zircon geochronology through robust downhole fractionation correction. Geochemistry, Geophys.

Geosystems 11. https://doi.org/10.1029/2009GC002618

Pearce, J.A., Norry, M.J., 1979. Petrogenetic implications of $\mathrm{Ti}, \mathrm{Zr}, \mathrm{Y}$, and $\mathrm{Nb}$ variations in volcanic rocks. Contrib. to Mineral. Petrol. 69, 33-47. https://doi.org/10.1007/BF00375192

Pearce, T.H., Gorman, B.E., Birkett, T.C., 1977. The relationship between major element chemistry and tectonic environment of basic and intermediate volcanic rocks. Earth Planet. Sci. Lett. 36, 121-132. https://doi.org/https://doi.org/10.1016/0012$821 \times(77) 90193-5$

Pearce, T.H., Gorman, B.E., Birkett, T.C., 1975. The TiO2-K2O-P2O5 diagram: A method of discriminating between oceanic and non-oceanic basalts. Earth Planet. Sci. Lett. 24, 419-426. https://doi.org/https://doi.org/10.1016/0012-821X(75)90149-1

Perkins, D., 2014. Mineralogy, 3rd ed. Pearson Educación, Harlow. 
1016 Pinheiro, S.S., Fernández, P.E.C.A., Pereira, E.., Vasconcelos, E.., Pinto, A.., Montalvão, 1017 R.M.., Issler, R.., Dall'Agnol, R., Teixeira, W., Fernández, C.A.C., 1976. Geología 1018 Projeto Radar na Amazônia. Folha NA.19-Pico da Neblina, in: Levantamento de 1019 Recursos Naturais- Vol 11. pp. 19-137.

1020 Pinson, W.H., Hurley, P.M., Mencher, E., Fairbairn, H.W., 1962. K-Ar AND Rb-Sr AGES OF 1021 BIOTITES FROM COLOMBIA, SOUTH AMERICA. Geol. Soc. Am. Bull. 73, 907-910. https://doi.org/10.1130/0016-7606(1962)73[907:KARAOB]2.0.CO;2

1023

1024

1025

1026

1027

1028

1029

1030

1031

1032

1033

1034

1035

1036

1037

1038

1039

1040

Pochon, A., Poujol, M., Gloaguen, E., Branquet, Y., Cagnard, F., Gumiaux, C., Gapais, D., 2016. U-Pb LA-ICP-MS dating of apatite in mafic rocks: Evidence for a major magmatic event at the Devonian-Carboniferous boundary in the Armorican Massif (France). Am. Mineral. 101, 2430-2442. https://doi.org/10.2138/am-2016-5736

Priem, H.N.A., Andriessen, P.A.M., Boelrijk, N.A.I.M., Boorder, H. de, Hebeda, E.H., Huguett, A., Verdurmen, E.A.T., Verschure, R.H., 1982. Geochronology of the Precambrian in the Amazonas Region of Southeastern Colombia (Western Guiana Shield). Geol. en Mijnb. 61, 229-242.

PRORADAM, 1979. La Amazonia Colombiana y sus recursos, in: Proyecto Radargramétrico Del Amazonas. Bogotá, p. 590.

Putzer, H., 1984. The geological evolution of the Amazon basin and its mineral resources. Springer, Dordrecht, pp. 15-46. https://doi.org/10.1007/978-94-009-6542-3_2

Rahn, M., Seward, D., 2000. How many tracks do we need? Newsl. Int. Fission-Track Commun 10, 12-15.

Ranst, G. Van, Pedrosa-Soares, A.C., Novo, T., Vermeesch, P., Grave, J. De, 2019. New insights from low-temperature thermochronology into the tectonic and geomorphologic evolution of the south-eastern Brazilian highlands and passive margin. Geosci. Front. https://doi.org/https://doi.org/10.1016/j.gsf.2019.05.011 
1041 Restrepo-Pace, P.A., 1995. Late Precambrian to Early Mesozoic tectonic evolution of the 1042 Colombian Andes, based on new geochronological, geochemical and isotopic data. 1043 Ph.D. Dissertation, University of Arizona, Tucson.

1044 Restrepo-Pace, P.A., Cediel, F., 2010. Northern South America basement tectonics and 1045 implications for paleocontinental reconstructions of the Americas. J. South Am. Earth 1046

Rivers, T., 1997. Lithotectonic elements of the Grenville Province. Review and tectonic implications. Precambrian Res. 86, 117-154.

1049

1050

1051

1052

1053

1054

1055

1056

1057

1058

1059

1060

1061

1062

1063

1064

1065 Sci. 29, 764-771. https://doi.org/10.1016/j.jsames.2010.06.002

Rodriguez, G., Sepulveda, J., Ramirez, C., Ortiz, F., Ramos, K., Bermúdez, J., Sierra, M., 2011. Unidades, Petrografía y composición quimica del Complejo migmatítico de Mitú. Boletín Geol. 33, 27-42.

Rollinson, H.R., 1993. Using Geochemical Data: Evaluation, Presentation, Interpretation. Longman.

Rossoni, M.B., Bastos Neto, A.C., Souza, V.S., Marques, J.C., Dantas, E., Botelho, N.F., Giovannini, A.L., Pereira, V.P., 2017. U-Pb zircon geochronologycal investigation on the Morro dos Seis Lagos Carbonatite Complex and associated Nb deposit (Amazonas, Brazil). J. South Am. Earth Sci. 80, 1-17. https://doi.org/10.1016/j.jsames.2017.09.021

Santos, J., Rizzotto, G., Potter, P.E., McNaughton, N.J., Matos, R.S., Hartmann, L.A., Chemale Junior, F., Quadros, M.E.S., 2008. Age and autochthonous evolution of the Sunsás Orogen in West Amazon Craton based on mapping and U-Pb geochronology. Precambrian Res. 165, 120-152.

Santos, J.O.S., Potter, P.E., Reis, N.J., Hartmann, L.A., Fletcher, I.R., McNaughton, N.J., 2003. Age, source, and regional stratigraphy of the Roraima Supergroup and Roraimalike outliers in northern South America based on U-Pb geochronology. Geol. Soc. Am. Bull. 115 $331-348$. https://doi.org/10.1130/0016- 
1067 Santos, J.O.S., Hartmann, L.A., Gaudette, H.E., Groves, D.I., Mcnaughton, N.J., Fletcher, 1068 I.R., 2000. A New Understanding of the Provinces of the Amazon Craton Based on 1069 Integration of Field Mapping and U-Pb and Sm-Nd Geochronology. Gondwana Res. 3, 453-488. https://doi.org/10.1016/S1342-937X(05)70755-3

1071 Schoene, B., Bowring, S.A., 2006. U-Pb systematics of the McClure Mountain syenite: 1072 thermochronological constraints on the age of the 40Ar/39Ar standard MMhb. Contrib. to 1073 Mineral. Petrol. 151, 615. https://doi.org/10.1007/s00410-006-0077-4

1074 1075 1076 1077 1078 1079 1080 1081 1082 1083 1084 1085 1086 1087 1088 1089 1090

Stacey, J.S., Kramers, J.D., 1975. Approximation of Terrestrial Lead Isotope Evolution by a 2Stage Model. Earth Planet. Sci. Lett. 26, 207-221.

Tassinari, C.C.G., 1996. O mapa Geocronológico do Craton Amazônico no Brasil: Revisões dos Dados Isotópicos 257.

Tassinari, C.C.G., Cordani, U.G., Nutman, A.P., Van Schmus, W.R., Bettencourt, J.S., Taylor, P.N., 1996. Geochronological Systematics on Basement Rocks from the Río NegroJuruena Province (Amazonian Craton) and Tectonic Implications. Int. Geol. Rev. 38, 161-175. https://doi.org/10.1080/00206819709465329

Tassinari, C.C.G., Macambira, M.J.B., 1999. Geochronological provinces of the Amazonian Craton. Episodes 22, 174-182. https://doi.org/10.1080/00206819709465329

Tassinari, C.G., Macambira, J.B., 2004. Geological provinces of the Amazonían Craton, in: Geología Do Continente Sul-Americano: Evolução Da Obra de Fernando Flávio Marques de Almeida. pp. 471-486.

Teixeira, W., Geraldes, M.C., Matos, R., Ruiz, A.S., Saes, G., Vargas-Mattos, G., 2010. A review of the tectonic evolution of the Sunsás belt, SW Amazonian Craton. J. South Am. Earth Sci. 29, 47-60. https://doi.org/10.1016/j.jsames.2009.09.007

Teixeira, W., Tassinari, C.C.G., Cordani, U.G., Kawashita, K., 1989. A review of the 
geochronology of the Amazonían Craton: Tectonic implications. Precambrian Res. 42, 213-227. https://doi.org/10.1016/0301-9268(89)90012-0

Teixeira, W., Tassinari, C.C.G., 1976. Geocronologia e consideracoes preliminares sobre a evolugao geológica da Folha NA.21 Pico da Neblina, in: Projeto RADAMBRASIL. Relatório Interno RADAMBRASIL, 67-G, Belém, p. 12.

Thomson, S., E. Gehrels, G., Ruiz, J., Buchwaldt, R., 2012. Routine low-damage apatite U$\mathrm{Pb}$ dating using laser ablation-multicollector-ICPMS. Geochemistry, Geophys. Geosystems 13. https://doi:10.1029/2011GC003928

Veras, R.S., 2012. Petrologia de granitóides dos arredores da Missão Tunuí, NW do Amazonas, Província Rio Negro, Cráton Amazônico. Dissertação. Departamento de Geociencias, Universidade Federal do Amazonas, Manaus.

Vermeesch, P., 2018. IsoplotR: a free and open toolbox for geochronology.

Vesga, C. Castillo, L., 1972. Reconocimiento geológico y Geoquímica preliminar del Río Guaviare, entre la confluencia con los ríos Ariari e Iteviare. Bogotá.

Villagómez, D., Spikings, R., 2013. Thermochronology and tectonics of the Central and Western Cordilleras of Colombia: Early Cretaceous-Tertiary evolution of the Northern Andes.

Lithos 160-161, 228-249. https://doi.org/https://doi.org/10.1016/j.lithos.2012.12.008

Wagner, G.A., Van den Haute, P., 1992. Fission-Track Dating. Ferdinand Enke Verlag, Stuttgart. https://doi.org/10.1007/978-94-011-2478-2

Wedepohl, K., 1995. The composition of the continental crust. Geochim. Cosmochim. Acta 59, 1217-1232. https://doi.org/10.1016/0016-7037(95)00038-2 
1116 Table 3 Operating conditions of the LA-ICP-MS equipment

\begin{tabular}{|c|c|}
\hline $\begin{array}{l}\text { Laboratory \& } \\
\text { Sample Preparation }\end{array}$ & \\
\hline Laboratory name & Géosciences Rennes, UMR CNRS 6118, Rennes, France \\
\hline Sample type/mineral & Magmatic apatite \\
\hline Sample preparation & $\begin{array}{l}\text { Conventional mineral separation, } 1 \text { inch resin mount, } 1 \mu \mathrm{m} \\
\text { polish to finish }\end{array}$ \\
\hline Imaging & $\begin{array}{l}\text { CL: RELION CL instrument, Olympus Microscope BX51WI, } \\
\text { Leica Color Camera DFC 420C }\end{array}$ \\
\hline $\begin{array}{l}\text { Laser ablation } \\
\text { system }\end{array}$ & \\
\hline Mark, Model \& type & ESI NWR193UC, Excimer \\
\hline Ablation cell & ESI NWR TwoVol2 \\
\hline Laser wavelength & $193 \mathrm{~nm}$ \\
\hline Pulse width & $<5 \mathrm{~ns}$ \\
\hline Fluence & $6.5 \mathrm{~J} / \mathrm{cm}-2$ sample AF-4, $6.5 \mathrm{~J} / \mathrm{cm}-2$ sample AF-7 \\
\hline Repetition rate & $5 \mathrm{~Hz}$ sample AF-4, $7 \mathrm{~Hz}$ sample AF-7 \\
\hline Spot size & $50 \mu \mathrm{m}$ sample AF-4, $30 \mu \mathrm{m}$ sample AF-7 \\
\hline $\begin{array}{l}\text { Sampling mode / } \\
\text { pattern }\end{array}$ & Single spot \\
\hline Carrier gas & $\begin{array}{l}100 \% \mathrm{He}, \mathrm{Ar} \text { make-up gas and } \mathrm{N} 2(3 \mathrm{ml} / \mathrm{mn}) \text { combined using } \\
\text { in-house smoothing device }\end{array}$ \\
\hline $\begin{array}{l}\text { Background } \\
\text { collection }\end{array}$ & 20 seconds \\
\hline Ablation duration & 60 seconds \\
\hline Wash-out delay & 15 seconds \\
\hline $\begin{array}{l}\text { Cell carrier gas flow } \\
(\mathrm{He})\end{array}$ & $0.75 \mathrm{I} / \mathrm{min}$ \\
\hline ICP-MS Instrument & \\
\hline Mark, Model \& type & Agilent 7700x, Q-ICP-MS \\
\hline Sample introduction & Via conventional tubing \\
\hline RF power & $1350 \mathrm{~W}$ \\
\hline $\begin{array}{l}\text { Sampler, skimmer } \\
\text { cones }\end{array}$ & $\mathrm{Ni}$ \\
\hline Extraction lenses & X type \\
\hline $\begin{array}{l}\text { Make-up gas flow } \\
\text { (Ar) }\end{array}$ & $0.87 \mathrm{I} / \mathrm{min}$ \\
\hline Detection system & Single collector secondary electron multiplier \\
\hline $\begin{array}{ll}\text { Data } & \text { acquisition } \\
\text { protocol } & \\
\end{array}$ & Time-resolved analysis \\
\hline Scanning mode & Peak hopping, one point per peak \\
\hline Detector mode & $\begin{array}{l}\text { Pulse counting, dead time correction applied, and analog } \\
\text { mode when signal intensity }>\sim 106 \mathrm{cps}\end{array}$ \\
\hline Masses measured & ${ }_{43} \mathrm{Ca}, 204(\mathrm{Hg}+\mathrm{Pb}), 206 \mathrm{~Pb}, 207 \mathrm{~Pb}, 208 \mathrm{~Pb}, 232 \mathrm{Th}, 238 \mathrm{U}$ \\
\hline $\begin{array}{l}\text { Integration time per } \\
\text { peak }\end{array}$ & $10-30 \mathrm{~ms}$ \\
\hline
\end{tabular}




\begin{tabular}{|l|l|}
\hline $\begin{array}{l}\text { Sensitivity / } \\
\text { Efficiency }\end{array}$ & $28000 \mathrm{cps} / \mathrm{ppm} \mathrm{Pb}(50 \mu \mathrm{m}, 10 \mathrm{~Hz})$ \\
\hline $\begin{array}{l}\text { Dwell time per } \\
\text { isotope }\end{array}$ & $5-70$ ms depending on the masses \\
\hline Data Processing & 20 seconds on-peak \\
\hline Gas blank & $\begin{array}{l}\text { Madagascar apatite used as primary reference material, } \\
\text { Durango and McClure apatites used as secondary reference } \\
\text { material (quality control) }\end{array}$ \\
\hline Calibration strategy \\
\hline $\begin{array}{l}\text { Reference Material } \\
\text { info }\end{array}$ & $\begin{array}{l}\text { Madagascar (Thomson et al., 2012) } \\
\text { Durango (McDowell et al., 2005) } \\
\text { McClure (Schoene and Bowring, 2006) }\end{array}$ \\
\hline $\begin{array}{l}\text { Data processing } \\
\text { package used }\end{array}$ & $\begin{array}{l}\text { lolite (Paton et al., 2010), VizualAge_UcomPbine (Chew et al., } \\
\text { 2014) }\end{array}$ \\
\hline $\begin{array}{l}\text { Quality control / } \\
\text { Validation }\end{array}$ & $\begin{array}{l}\text { Durango: Wtd ave 207Pb corrected age }=32.29 \pm 0.76 \mathrm{Ma} \\
(\mathrm{N}=5, \mathrm{MSWD}=0.76 ; \text { probability=0.92) } \\
\text { McClure: Wtd ave 207Pb corrected age }=520.3 \pm 8.8 \mathrm{Ma} \\
(\mathrm{N}=3, \mathrm{MSWD}=0.47 ; \text { probability }=0.78)\end{array}$ \\
\hline
\end{tabular}

1118 Table 4 U-Pb LA-ICP-MS data of apatite crystals from Caño Viejita gabbro samples AF-1 and 1119 AF-7.

\begin{tabular}{|l|l|r|l|r|r|r|r|r|}
\hline $\begin{array}{l}\text { ANALY } \\
\text { SIS \# }\end{array}$ & $\begin{array}{l}\text { 238U/ } \\
\text { 206 Pb }\end{array}$ & $\begin{array}{l}\text { PropErr } \\
\text { 2Sig\% }\end{array}$ & $\begin{array}{l}\text { 207Pb/ } \\
\text { 206Pb }\end{array}$ & $\begin{array}{l}\text { PropErr } \\
\text { 2Sig\% }\end{array}$ & $\begin{array}{l}\text { Approx_- } \\
\text { U_PPM }\end{array}$ & $\begin{array}{l}\text { Approx_P PPM } \\
\text { b_PPI }\end{array}$ & $\begin{array}{l}\text { Final } \\
\text { 207Age }\end{array}$ & $\begin{array}{l}\text { PropErr2S } \\
\text { igAbs. }\end{array}$ \\
\hline AF-1.1 & 3.178 & 5.7 & 0.4660 & 2.4 & 1.4 & 1.2 & 997 & 50 \\
\hline AF-1.2 & 3.617 & 5.8 & 0.4180 & 2.6 & 1.3 & 1.0 & 973 & 58 \\
\hline AF-1.3 & 3.890 & 3.1 & 0.3872 & 2.2 & 1.7 & 1.2 & 960 & 47 \\
\hline AF-1.4 & 3.601 & 3.0 & 0.4199 & 2.3 & 1.2 & 0.9 & 974 & 56 \\
\hline AF-1.5 & 3.778 & 2.9 & 0.4041 & 2.1 & 1.2 & 0.9 & 959 & 51 \\
\hline AF-1.7 & 3.769 & 3.0 & 0.3952 & 1.9 & 1.5 & 1.1 & 973 & 45 \\
\hline AF-1.8 & 3.113 & 3.1 & 0.4060 & 2.5 & 1.1 & 0.9 & 965 & 55 \\
\hline AF-1.9 & 3.736 & 3.0 & 0.4062 & 2.2 & 1.2 & 0.9 & 966 & 53 \\
\hline AF-1.10 & 3.729 & 3.0 & 0.4190 & 2.4 & 1.1 & 0.8 & 943 & 56 \\
\hline AF-1.11 & 3.730 & 3.0 & 0.3990 & 2.5 & 1.1 & 0.8 & 980 & 54 \\
\hline AF-1.12 & 3.575 & 3.1 & 0.4250 & 2.6 & 1.2 & 0.9 & 971 & 57 \\
\hline AF-1.13 & 3.428 & 3.0 & 0.4378 & 2.3 & 1.3 & 1.1 & 985 & 56 \\
\hline AF-1.14 & 3.840 & 3.0 & 0.3823 & 2.3 & 1.4 & 1.0 & 977 & 50 \\
\hline AF-1.15 & 3.792 & 2.8 & 0.3883 & 1.8 & 1.7 & 1.2 & 976 & 46 \\
\hline AF-1.16 & 3.733 & 2.9 & 0.3884 & 2.3 & 1.5 & 1.1 & 999 & 52 \\
\hline AF-1.17 & 3.617 & 2.9 & 0.4050 & 2.5 & 1.2 & 0.9 & 997 & 58 \\
\hline AF-1.18 & 3.818 & 2.9 & 0.3816 & 2.2 & 1.6 & 1.1 & 989 & 52 \\
\hline
\end{tabular}




\begin{tabular}{|c|c|c|c|c|c|c|c|c|}
\hline$A F-1.19$ & 3.586 & 2.9 & 0.4148 & 2.1 & 1.2 & 0.9 & 984 & 52 \\
\hline AF-1.20 & 3.658 & 3.0 & 0.4074 & 2.3 & 1.4 & 1.0 & 983 & 50 \\
\hline AF-1.21 & 3.744 & 3.0 & 0.3883 & 2.2 & 1.3 & 0.9 & 997 & 51 \\
\hline AF-1.22 & 3.552 & 3.0 & 0.4045 & 2.2 & 1.3 & 1.0 & 1015 & 56 \\
\hline$A F-1.23$ & 3.689 & 2.9 & 0.3965 & 2.1 & 1.4 & 1.0 & 989 & 52 \\
\hline AF-1.24 & 3.675 & 3.0 & 0.4030 & 2.7 & 1.1 & 0.8 & 985 & 57 \\
\hline AF-1.25 & 3.685 & 3.0 & 0.4140 & 2.4 & 1.1 & 0.8 & 962 & 60 \\
\hline AF-7.1 & 3.906 & 6.2 & 0.4010 & 9.2 & 2.3 & 1.3 & 950 & 120 \\
\hline AF-7.2 & 3.610 & 7.2 & 0.4320 & 11.6 & 1.4 & 0.9 & 980 & 140 \\
\hline AF-7.3 & 3.623 & 8.0 & 0.4120 & 10.9 & 1.3 & 0.9 & 1020 & 160 \\
\hline AF-7.4 & 3.268 & 8.8 & 0.4210 & 10.7 & 1.2 & 0.8 & 1090 & 170 \\
\hline AF-7.5 & 3.636 & 6.9 & 0.3920 & 10.5 & 1.6 & 0.9 & 1040 & 130 \\
\hline AF-7.6 & 3.195 & 7.7 & 0.4310 & 9.7 & 1.2 & 0.9 & 1100 & 160 \\
\hline AF-7.7 & 3.484 & 7.7 & 0.5170 & 10.6 & 1.7 & 1.3 & 880 & 140 \\
\hline AF-7.8 & 3.300 & 7.3 & 0.4220 & 10.7 & 1.3 & 0.8 & 1110 & 150 \\
\hline AF-7.9 & 3.300 & 8.3 & 0.4180 & 10.3 & 1.1 & 0.7 & 1080 & 150 \\
\hline AF-7.10 & 3.759 & 8.6 & 0.3890 & 12.1 & 1.2 & 0.8 & 990 & 150 \\
\hline AF-7.11 & 3.597 & 7.6 & 0.4070 & 10.1 & 1.6 & 1.0 & 1040 & 140 \\
\hline AF-7.12 & 3.322 & 7.6 & 0.4250 & 10.6 & 1.2 & 0.9 & 1080 & 160 \\
\hline AF-7.13 & 3.559 & 7.5 & 0.4030 & 10.2 & 1.2 & 0.9 & 1060 & 140 \\
\hline AF-7.14 & 3.521 & 6.3 & 0.3900 & 7.7 & 1.9 & 1.2 & 1063 & 120 \\
\hline AF-7.15 & 3.759 & 6.4 & 0.3670 & 7.6 & 2.3 & 1.5 & 1062 & 110 \\
\hline AF-7.16 & 2.591 & 7.5 & 0.5240 & 8.6 & 1.4 & 1.3 & 1130 & 190 \\
\hline AF-7.17 & 2.695 & 8.1 & 0.5530 & 10.1 & 0.9 & 0.8 & 1000 & 230 \\
\hline AF-7.18 & 3.096 & 8.0 & 0.4690 & 11.3 & 1.5 & 1.0 & 1070 & 170 \\
\hline AF-7.19 & 3.534 & 10.6 & 0.5050 & 14.3 & 1.0 & 0.5 & 900 & 190 \\
\hline AF-7.20 & 2.028 & 7.5 & 0.5740 & 7.3 & 1.6 & 1.9 & 1120 & 190 \\
\hline AF-7.21 & 1.570 & 7.1 & 0.6790 & 6.2 & 1.4 & 2.4 & 990 & 230 \\
\hline AF-7.22 & 3.521 & 8.5 & 0.4560 & 12.1 & 1.3 & 0.8 & 1000 & 170 \\
\hline AF-7.23 & 3.436 & 8.9 & 0.4360 & 12.6 & 1.1 & 0.6 & 990 & 170 \\
\hline AF-7.24 & 3.125 & 6.6 & 0.4590 & 9.2 & 1.9 & 1.4 & 1080 & 150 \\
\hline AF-7.25 & 3.436 & 8.9 & 0.4860 & 13.0 & 1.0 & 0.7 & 1000 & 190 \\
\hline AF-7.26 & 3.367 & 8.4 & 0.3950 & 10.9 & 1.1 & 0.7 & 1130 & 180 \\
\hline AF-7.27 & 3.690 & 7.4 & 0.3930 & 9.9 & 1.8 & 1.0 & 1020 & 140 \\
\hline AF-7.28 & 3.650 & 8.4 & 0.4150 & 12.3 & 1.3 & 0.7 & 1010 & 150 \\
\hline AF-7.29 & 3.279 & 7.9 & 0.4150 & 11.6 & 1.4 & 0.8 & 1110 & 170 \\
\hline AF-7.30 & 3.636 & 8.0 & 0.4720 & 12.5 & 1.4 & 0.8 & 910 & 160 \\
\hline
\end{tabular}




\begin{tabular}{|r|r|r|r|r|r|r|r|r|} 
AF-7.31 & 3.472 & 8.3 & 0.4350 & 11.3 & 1.1 & 0.6 & 970 & 170 \\
\hline AF-7.32 & 3.279 & 7.2 & 0.4270 & 11.9 & 1.3 & 0.7 & 1110 & 170 \\
\hline AF-7.33 & 3.247 & 8.8 & 0.4070 & 10.6 & 1.1 & 0.6 & 1130 & 160 \\
\hline AF-7.34 & 3.205 & 7.4 & 0.4460 & 11.7 & 1.2 & 0.9 & 1080 & 180 \\
\hline AF-7.35 & 3.378 & 7.8 & 0.4740 & 9.7 & 1.1 & 0.9 & 960 & 160 \\
\hline
\end{tabular}


Table 5 Apatite fission tracks results. $\mathrm{N}$ is the number of analyzed grains, $\mathrm{N}_{\mathrm{s}}$ represents the number of spontaneous tracks counted in total, A represents the total area in which $\mathrm{N}_{\mathrm{s}}$ were measured distributed over all 33 grains. The Average and Average Weighted ${ }_{238} \mathrm{U} / 43 \mathrm{Ca}$ ratios are based on each individual ${ }_{238} \mathrm{U} / 43 \mathrm{Ca}$ ratio and are used as a proxy for the Uranium concentration of each apatite grain. The samples pass the chi-squared probability test $(>0.05)$. Chlorine content given in weight percentage and with synthetic apatite $(6.81$ wt\% $\mathbf{C l}$, Klemme et al., 2013). The mean length (Im), number of tracks lengths (nı) and standard deviation is also displayed.

\begin{tabular}{|l|l|l|l|l|l|l|l|l|l|l|l|l|l|}
\hline Sample & $\mathrm{N}$ & $\mathrm{N}_{\mathrm{s}}$ & $\begin{array}{l}\mathrm{A} \\
(10-3 \\
\mathrm{cm} 2)\end{array}$ & $\begin{array}{l}\text { Average } \\
238 \mathrm{U} / 43 \mathrm{Ca}\end{array}$ & $\begin{array}{l}\text { Average } \\
\text { Weighted } \\
238 \mathrm{U} / 43 \mathrm{Ca}\end{array}$ & $\begin{array}{l}\text { Central } \\
\text { age } \pm 1 \sigma \\
(\mathrm{Ma})\end{array}$ & $\begin{array}{l}\text { Pooled } \\
\text { age } \pm 1 \sigma \\
(\mathrm{Ma})\end{array}$ & $\mathrm{P}\left(\mathrm{X}^{2}\right)$ & $\begin{array}{l}\text { Chlorine } \\
\text { content } \\
\pm 1 \sigma(\mathrm{w} \%)\end{array}$ & $\begin{array}{l}\mathrm{Im}(\mu \mathrm{m}) \\
\mathrm{n} /\end{array}$ & $\sigma(\mu \mathrm{m})$ \\
\hline AF-7 & 33 & 404 & 3.35 & 0.0888 & 0.00934 & $179.8 \pm 9.0$ & $173.3 \pm 9.2$ & 0.58 & $0.28 \pm 0.13$ & 11.84 & 47 & 1.87 \\
\hline
\end{tabular}

